Supporting Information

\title{
Strengthening Polyethylene Thermoplastic through A Dynamic Covalent Networking Additive Based on Alkylboron Chemistry
}

\author{
Zongtao Wang, Yu Gu, Mingyu Ma, Yinli Liu, Mao Chen* \\ State Key Laboratory of Molecular Engineering of Polymers, Department of Macromolecular Science, \\ Fudan University, Shanghai 200433, P. R. China \\ *E-mail: chenmao@fudan.edu.cn
}




\section{Table of Contents}

1. General information of materials and characterization methods

2. Synthesis and characterization of monomers and other compounds

3. Preparation and characterization of polymer networks.

4. Swelling and hydrolysis experiment

5. Characterizations of PE materials 


\section{General information of materials and characterization methods}

\subsection{Materials}

1,5-Cyclooctadiene, cyclooctene (COE), 3-chloroperoxybenzoic acid (m-CPBA), methylboronic acid (MBA), propylboronic acid (PBA), (2-methylpropyl)boronic acid, 1,6dibromohexane (DBH), Grubbs' second generation catalyst, 1,2-propanediol (PPD), 1,2butanediol, phenylboronic acid (PBA), trimethyl borate (TMB), o-xylene, 4methylbenzenesulfonhydrazide, 2,6-di-tert-butylphenol were purchased from Adamas, SigmaAldrich or TCI. Concentrated sulfuric acid (98\%) and hydrochloric acid ( $\mathrm{HCl})$ were obtained from Sinopharm Chemical Reagent Co. Ltd. Low density polyethylene (LDPE) was obtained from Sinopec (brand 1I70A).

Magnesium powder was washed with ammonium chloride solution and acetone successively, and dried under vacuum before use. $o$-Xylene, dichloromethane (DCM) were freshly distilled from $\mathrm{CaH}_{2}$ before use. Methanol was distilled from anhydrous $\mathrm{CaCl}_{2}$ before use. Tetrahydrofuran (THF) was distilled over sodium wire. Other reagents and solvents were used as received without further purification.

\subsection{Characterization methods}

Gas chromatography (GC) was conducted on a Shimadzu GC-2014 using nitrogen as carrier gas. Nuclear magnetic resonance (NMR) measurements were recorded with an Advance III 400 $\mathrm{MHz}$ Bruker spectrometer at $298 \mathrm{~K} .{ }^{1} \mathrm{H}$ NMR signals were measured relative to the signal for residual chloroform $(7.26 \mathrm{ppm})$ in deuterochloroform $\left(\mathrm{CDCl}_{3}\right)$, and are reported in $\delta$ units, parts per million (ppm). High resolution mass spectra (HRMS) were measured on a JEOL AccuTOFGCv 4G GCT mass spectrometer. Size exclusion chromatography (SEC) measurements were performed in THF at $35{ }^{\circ} \mathrm{C}$ with an elution rate of $1.0 \mathrm{~mL} / \mathrm{min}$ on an Agilent 1100 instrument equipped with a G1310A pump and a G1362A refractive index detector. Three columns were employed including one $5 \mu \mathrm{m}$ LP gel column (molecular range $500 \sim 2 \times 10^{4} \mathrm{~g} \mathrm{~mol}^{-1}$ ) and two 5 $\mu \mathrm{m}$ LP gel mixed bed columns (molecular range $200 \sim 3 \times 10^{6} \mathrm{~g} \mathrm{~mol}^{-1}$ ). The calibration was performed with polystyrene standards. Attenuated total reflection infrared (ATR-IR) spectra were collected using a Nicolet 6700 spectrometer with a diamond ATR probe. Thermogravimetric analysis (TGA) was performed on a Mettler Toledo TGA/SDTA851e instrument under nitrogen flow at a heating rate of $20 \mathrm{~K} \cdot \mathrm{min}^{-1}$. Differential scanning calorimetry (DSC) was performed using a TA Instrument Q2000 at a heating rate of $10{ }^{\circ} \mathrm{C} \cdot \mathrm{min}^{-}$ ${ }^{1}$ under nitrogen atmosphere. Dynamic mechanical analyses (DMA) were carried out on a 
Mettler Toledo DMA/SDTA861e using a tension clamp. Rectangular specimens with a dimension of $20 \mathrm{~mm} \times 5 \mathrm{~mm} \times 0.5 \mathrm{~mm}$ were prepared for characterization. A temperature ranging from 0 to $150{ }^{\circ} \mathrm{C}$ was performed at a rate of $3{ }^{\circ} \mathrm{C} \cdot \mathrm{min}^{-1}$ with an amplitude of $15 \mu \mathrm{m}$ and a frequency of $1 \mathrm{~Hz}$.

Rheological studies and viscoelastic behaviors were investigated by a HAAKE MARS III rheometer using $20 \mathrm{~mm}$ parallel plates. For oscillation sweep experiments, a strain of 1\% was applied under different frequencies. The storage modulus $\left(G^{\prime}\right)$ and loss modulus $\left(G^{\prime \prime}\right)$ measured at $120{ }^{\circ} \mathrm{C}$. For stress relaxation experiments, investigations were conducted in a range from 120 to $160{ }^{\circ} \mathrm{C}$ by applying a constant shear strain of $1 \%$. The relaxation modulus $(\mathrm{G}(\mathrm{t}))$ was followed over time at a constant temperature.

Tensile tests were investigated using dumbbell-shaped specimens (effective gauge length $=$ $12 \mathrm{~mm}$, width $=2 \mathrm{~mm}$, thickness $=0.5 \mathrm{~mm}$ ) via an Instron 5966 universal testing machine equipped with an oven and a $1 \mathrm{kN}$ sensor. Measurements were performed using a preload of about $0.01 \mathrm{~N}$ and a pulling speed of $1 \mathrm{~mm} / \mathrm{min}$ until sample failure. Tensile tests were carried out at room temperature or higher temperature $\left(60{ }^{\circ} \mathrm{C}, 80{ }^{\circ} \mathrm{C}\right.$ and $\left.100{ }^{\circ} \mathrm{C}\right)$. The stress $\sigma$ was recorded as a function of strain $\varepsilon(\%)$. Reported values (elongation (\%), stress at break (MPa) and Young's modulus (GPa)) were the average and standard deviations of at least five samples.

For compression molding, polymer materials were shaped (5 min, $2 \mathrm{MPa}$ ) into square plate $(100 \mathrm{~mm} \times 100 \mathrm{~mm} \times 0.5 \mathrm{~mm})$ at $160{ }^{\circ} \mathrm{C}$. Samples with disc-shape (diameter $\left.=20 \mathrm{~mm}\right)$, barshape $(20 \mathrm{~mm} \times 5 \mathrm{~mm})$ and dumbbell-shape (effective gauge length $=12 \mathrm{~mm}$, width $=2 \mathrm{~mm}$ ) were prepared for corresponding analyses.

\section{Synthesis and characterization of monomers and other compounds}

\subsection{General procedure for the preparation of small molecular boronic esters}

A round-bottom flask equipped with a stir bar was charged with boronic acid (1.0 eq), diol (1.0 eq) and anhydrous THF. After stirring at room temperature for $1 \mathrm{~h}$, anhydrous $\mathrm{MgSO}_{4}(3.0$ eq) was added into the flask, and the mixture was stirred at room temperature for further $4 \mathrm{~h}$. After reaction, the mixture was filtered. The obtained filtrate was concentrated under reduced pressure to give the crude product as a colorless oil. The crude product was then treated with anhydrous hexane, filtered and concentrated under reduced pressure to give target compound as a colorless oil. 


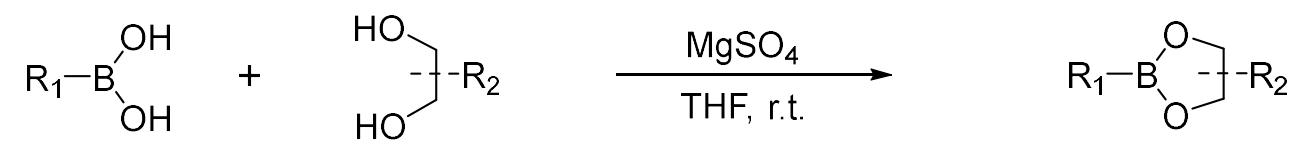

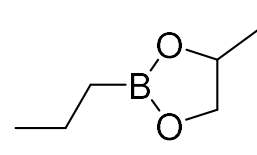

$\mathrm{B}_{1}-\mathrm{C}_{1}$

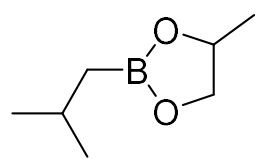

$\mathrm{B}_{2}-\mathrm{C}_{1}$

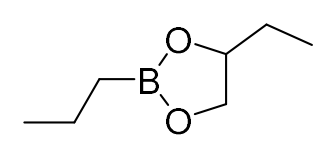

$\mathrm{B}_{1}-\mathrm{C}_{2}$

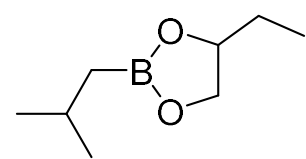

$\mathrm{B}_{2}-\mathrm{C}_{2}$

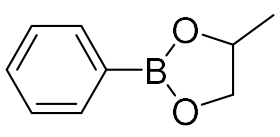

$\mathrm{A}_{1}-\mathrm{C}_{1}$

Scheme S1. Preparation of small molecular boronic esters.

B1-C1. ${ }^{1} \mathrm{H}$ NMR $\left(400 \mathrm{MHz}, \mathrm{CDCl}_{3}\right) \delta:$ 4.58-4.50 (m, 1H), $4.28(\mathrm{t}, J=8.4 \mathrm{~Hz}, 1 \mathrm{H}), 3.71$ (t, $J=8.0 \mathrm{~Hz}, 1 \mathrm{H}), 1.51-1.42(\mathrm{~m}, 2 \mathrm{H}), 1.32(\mathrm{dd}, J=6.0 \mathrm{~Hz}, 1.2 \mathrm{~Hz}, 3 \mathrm{H}), 0.96(\mathrm{t}, J=7.2 \mathrm{~Hz}, 3 \mathrm{H})$, $0.84(\mathrm{t}, J=7.6 \mathrm{~Hz}, 2 \mathrm{H})$ ppm. ${ }^{13} \mathrm{C} \mathrm{NMR}\left(100 \mathrm{MHz}, \mathrm{CDCl}_{3}\right): \delta 72.9,71.9,21.8,17.4,16.9 \mathrm{ppm}$. Similar to previous reports, carbon adjacent to boron is not detected. ${ }^{1-2}$ HRMS (ESI-TOF): $\mathrm{m} / \mathrm{z}$ calculated for $\mathrm{C}_{6} \mathrm{H}_{13} \mathrm{BO}_{2}[\mathrm{M}]^{+}$: 127.1039, found: 127.1041 .

B2-C1. $^{1} \mathrm{H}$ NMR (400 MHz, $\left.\mathrm{CDCl}_{3}\right) \delta$ : 4.56-4.48 (m, 1H), 4.27-4.23 (t, $\left.J=8.8 \mathrm{~Hz}, 1 \mathrm{H}\right)$, $3.71-3.67(\mathrm{dd}, J=8.8,2.0 \mathrm{~Hz}, 1 \mathrm{H}), 1.91-1.81(\mathrm{~m}, 1 \mathrm{H}), 1.32$ (d, $J=6.0 \mathrm{~Hz}, 3 \mathrm{H}), 0.94(\mathrm{~d}, J=6.4$ $\mathrm{Hz}, 6 \mathrm{H}), 0.80(\mathrm{~d}, J=7.2 \mathrm{~Hz}, 2 \mathrm{H}) \mathrm{ppm} .{ }^{13} \mathrm{C} \mathrm{NMR}\left(100 \mathrm{MHz}, \mathrm{CDCl}_{3}\right): \delta 77.8,70.1,28.9,17.4$, $16.9,8.9 \mathrm{ppm}$. Similar to previous reports, carbon adjacent to boron is not detected. ${ }^{1-2}$ HRMS (ESI-TOF): $m / z$ calculated for $\mathrm{C}_{7} \mathrm{H}_{15} \mathrm{BO}_{2}[\mathrm{M}]^{+}:$141.1196, found: 141.1195 .

B1-C2. ${ }^{1} \mathrm{H}$ NMR (400 MHz, $\left.\mathrm{CDCl}_{3}\right) \delta$ : 4.37-4.30 (m, 1H), 4.25-4.21 (t, $\left.J=8.8 \mathrm{~Hz}, 1 \mathrm{H}\right)$, 3.80-3.76 (dd, $J=8.8,1.6 \mathrm{~Hz}, 1 \mathrm{H}), 1.68-1.54(\mathrm{~m}, 2 \mathrm{H}), 1.51-1.42(\mathrm{~m}, 2 \mathrm{H}), 0.97-0.93(\mathrm{~m}, 6 \mathrm{H})$, $0.83(\mathrm{t}, J=7.6 \mathrm{~Hz}, 2 \mathrm{H})$ ppm. ${ }^{13} \mathrm{C} \mathrm{NMR}\left(100 \mathrm{MHz}, \mathrm{CDCl}_{3}\right): \delta 72.9,71.9,25.2,24.8,21.8 \mathrm{ppm}$. Similar to previous reports, carbon adjacent to boron is not detected. ${ }^{1-2}$ HRMS (ESI-TOF): $m / z$ calculated for $\mathrm{C}_{7} \mathrm{H}_{15} \mathrm{BO}_{2}[\mathrm{M}]^{+}$: 141.1196, found: 141.1198 .

B2-C2. ${ }^{1} \mathrm{H}$ NMR (400 MHz, $\left.\mathrm{CDCl}_{3}\right) \delta: 4.38-4.31(\mathrm{~m}, 1 \mathrm{H}), 4.23(\mathrm{t}, J=8.8 \mathrm{~Hz}, 1 \mathrm{H}), 3.78$ $(\mathrm{dd}, J=8.8 \mathrm{~Hz}, 2.0 \mathrm{~Hz}, 1 \mathrm{H}), 1.93-1.83(\mathrm{~m}, 1 \mathrm{H}), 1.70-1.54(\mathrm{~m}, 2 \mathrm{H}), 0.99-0.95(\mathrm{~m}, 9 \mathrm{H}), 0.80$ (d, $J=7.2 \mathrm{~Hz}, 2 \mathrm{H}) \mathrm{ppm} .{ }^{13} \mathrm{C} \mathrm{NMR}\left(100 \mathrm{MHz}, \mathrm{CDCl}_{3}\right): \delta 77.8,70.0,29.0,25.2,24.8,8.9 \mathrm{ppm}$. Similar to previous reports, carbon adjacent to boron is not detected. ${ }^{1-2}$ HRMS (ESI-TOF): $\mathrm{m} / \mathrm{z}$ calculated for $\mathrm{C}_{8} \mathrm{H}_{17} \mathrm{BO}_{2}[\mathrm{M}]^{+}:$155.1352, found: 155.1349 .

A1-C1. ${ }^{1}{ }^{1} \mathrm{H}$ NMR $\left(400 \mathrm{MHz}, \mathrm{CDCl}_{3}\right) \delta: 7.83(\mathrm{~d}, J=6.8 \mathrm{~Hz}, 2 \mathrm{H}), 7.50(\mathrm{t}, J=7.2 \mathrm{~Hz}, 1 \mathrm{H})$, $7.41(\mathrm{t}, J=7.2 \mathrm{~Hz}, 2 \mathrm{H}), 4.80-4.71(\mathrm{~m}, 1 \mathrm{H}), 7.43-4.39(\mathrm{~m}, 1 \mathrm{H}), 4.64(\mathrm{dd}, J=8.8,1.2 \mathrm{~Hz}, 1 \mathrm{H})$, $3.90(\mathrm{dd}, J=8.8,1.6 \mathrm{~Hz}, 1 \mathrm{H}), 1.43(\mathrm{~d}, J=6.4 \mathrm{~Hz}, 3 \mathrm{H}) \mathrm{ppm}$. 

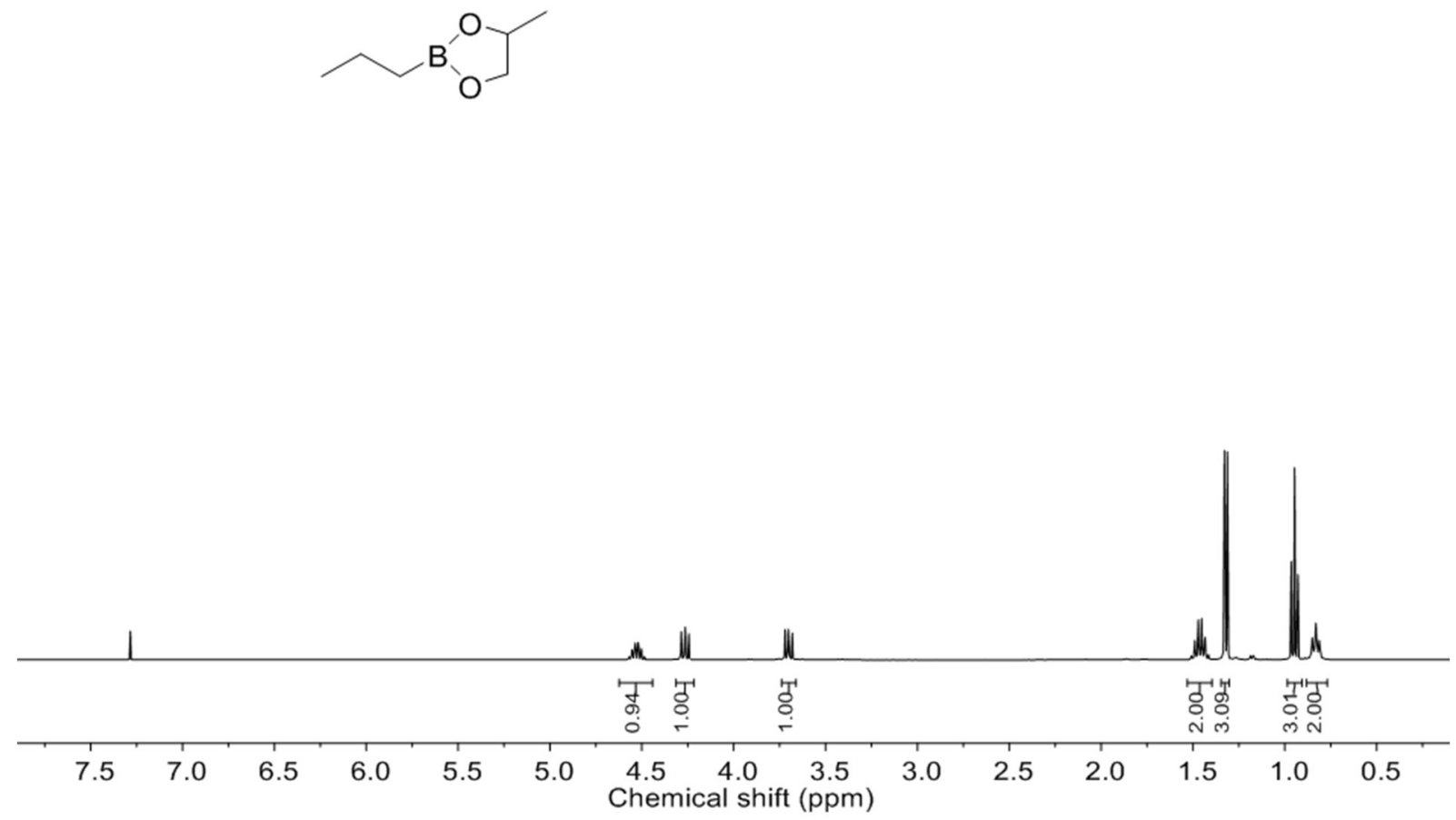

Figure S1. ${ }^{1} \mathrm{H} \mathrm{NMR}$ spectrum of $\mathrm{B}_{1}-\mathrm{C}_{1}\left(400 \mathrm{MHz}, \mathrm{CDCl}_{3}\right)$.

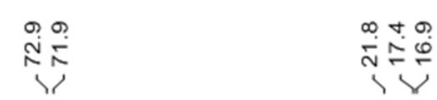<smiles>CCCB1OCC(C)O1</smiles>

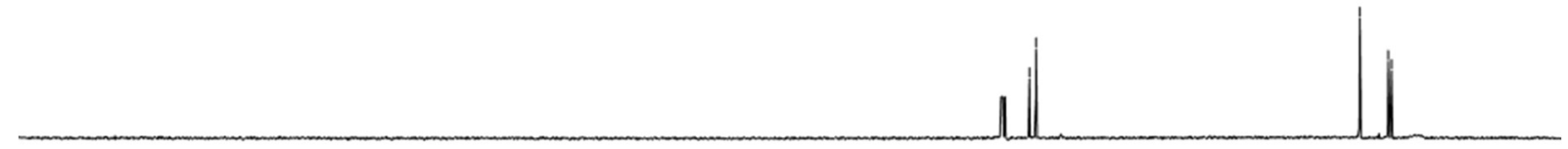

$\left.220210200190180170160150140 \begin{array}{c}130 \quad 120 \\ \text { chemical shift (ppm) }\end{array}\right)$

Figure S2. ${ }^{13} \mathrm{C}$ NMR spectrum of $\mathrm{B}_{1}-\mathrm{C}_{1}\left(100 \mathrm{MHz}, \mathrm{CDCl}_{3}\right)$. 
<smiles>CC(C)CB1OCC(C)O1</smiles>

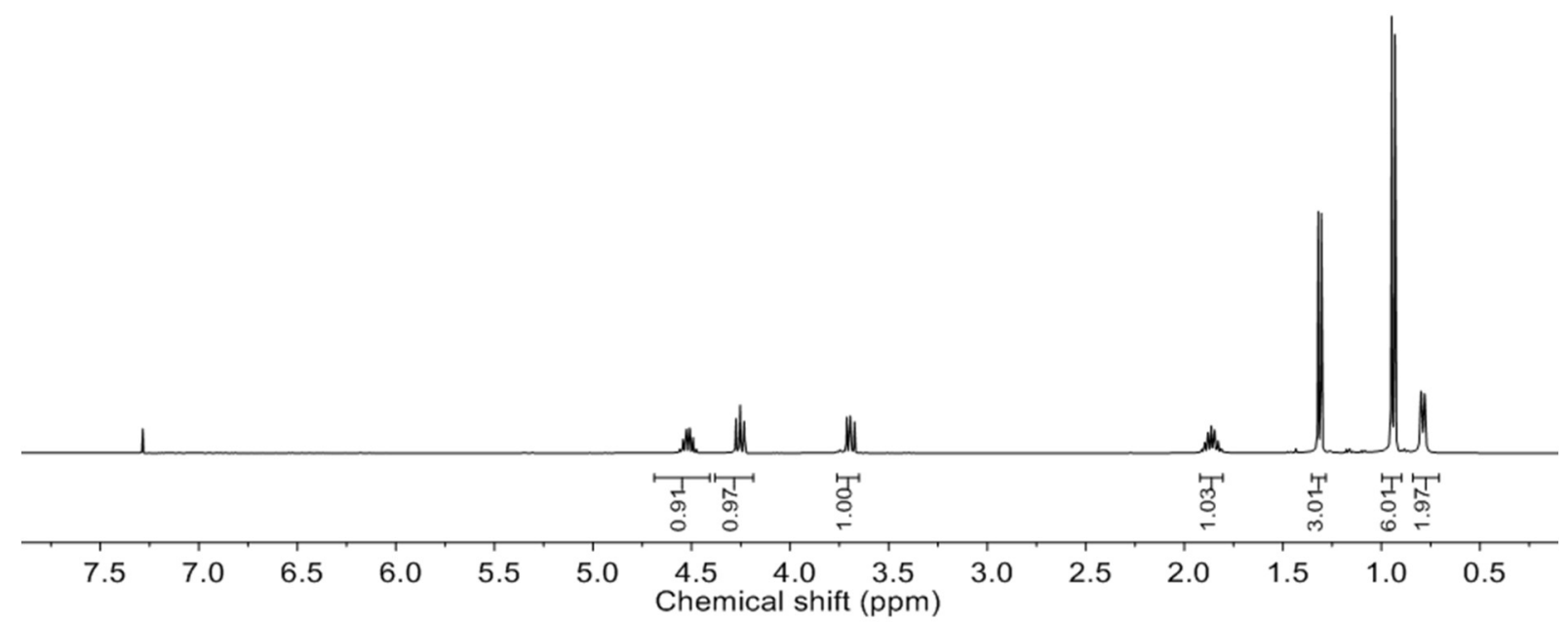

Figure S3. ${ }^{1} \mathrm{H}$ NMR spectrum of $\mathrm{B}_{2}-\mathrm{C}_{1}\left(400 \mathrm{MHz}, \mathrm{CDCl}_{3}\right)$.<smiles>CC(C)CB1OCC(C)O1</smiles>

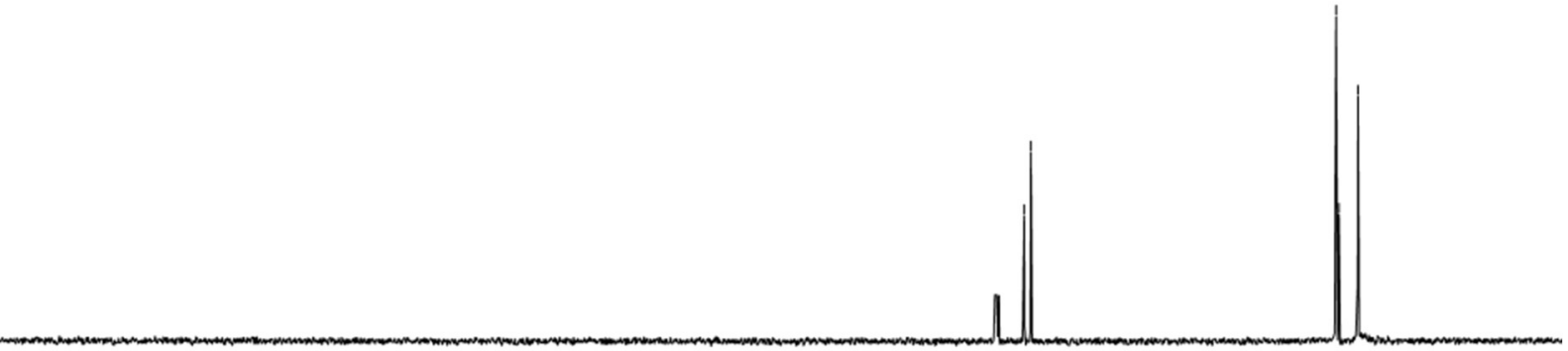

$220210200190180170160150140130 \begin{gathered}120 \quad 110 \quad 100 \\ \text { Chemical shift }\end{gathered}$

Figure S4. ${ }^{13} \mathrm{C}$ NMR spectrum of $\mathrm{B}_{2}-\mathrm{C}_{1}\left(100 \mathrm{MHz}, \mathrm{CDCl}_{3}\right)$. 
<smiles>CCCB1OCC(CC)O1</smiles>

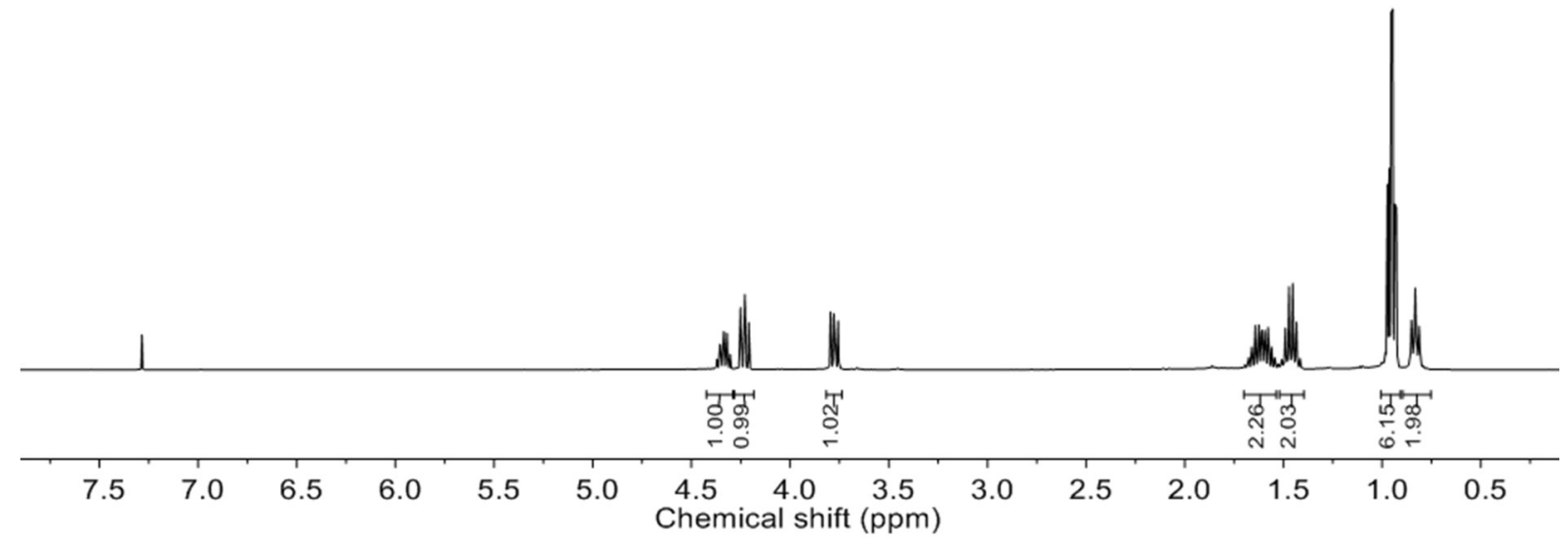

Figure S5. ${ }^{1} \mathrm{H} \mathrm{NMR}$ spectrum of $\mathrm{B}_{1}-\mathrm{C}_{2}\left(400 \mathrm{MHz}, \mathrm{CDCl}_{3}\right)$.

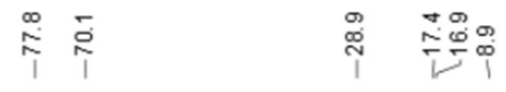<smiles>CCCB1OCC(CC)O1</smiles>

$220210200190180170160150140130120110 \quad 100 \quad 90 \quad 80 \quad 70 \quad 60 \begin{array}{lllllll}50 & 40 & 30 & 20 & 10 & 0\end{array}$ Chemical shift (ppm)

Figure S6. ${ }^{13} \mathrm{C}$ NMR spectrum of $\mathrm{B}_{1}-\mathrm{C}_{2}\left(100 \mathrm{MHz}, \mathrm{CDCl}_{3}\right)$. 
<smiles>CCC1COB(CC(C)C)O1</smiles>

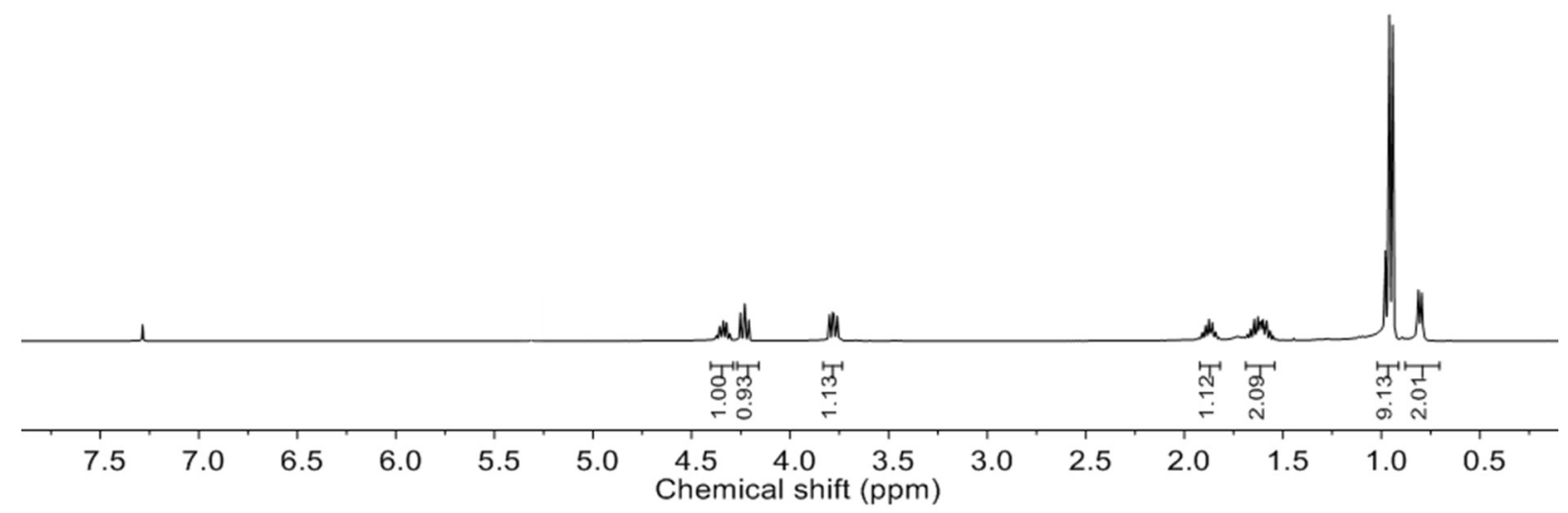

Figure S7. ${ }^{1} \mathrm{H}$ NMR spectrum of $\mathrm{B}_{2}-\mathrm{C}_{2}\left(400 \mathrm{MHz}, \mathrm{CDCl}_{3}\right)$.

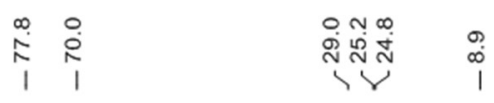<smiles>CCC1COB(CC(C)C)O1</smiles>

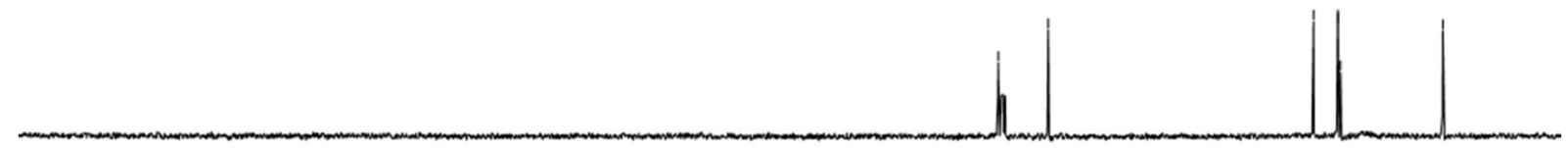

$220210200190180170160150140130120110100 \quad 90 \quad 80 \quad 70 \quad 60 \begin{array}{llllllll}50 & 40 & 30 & 20 & 10 & 0\end{array}$ Chemical shift

Figure S8. ${ }^{13} \mathrm{C}$ NMR spectrum of $\mathrm{B}_{2}-\mathrm{C}_{2}\left(100 \mathrm{MHz}, \mathrm{CDCl}_{3}\right)$. 

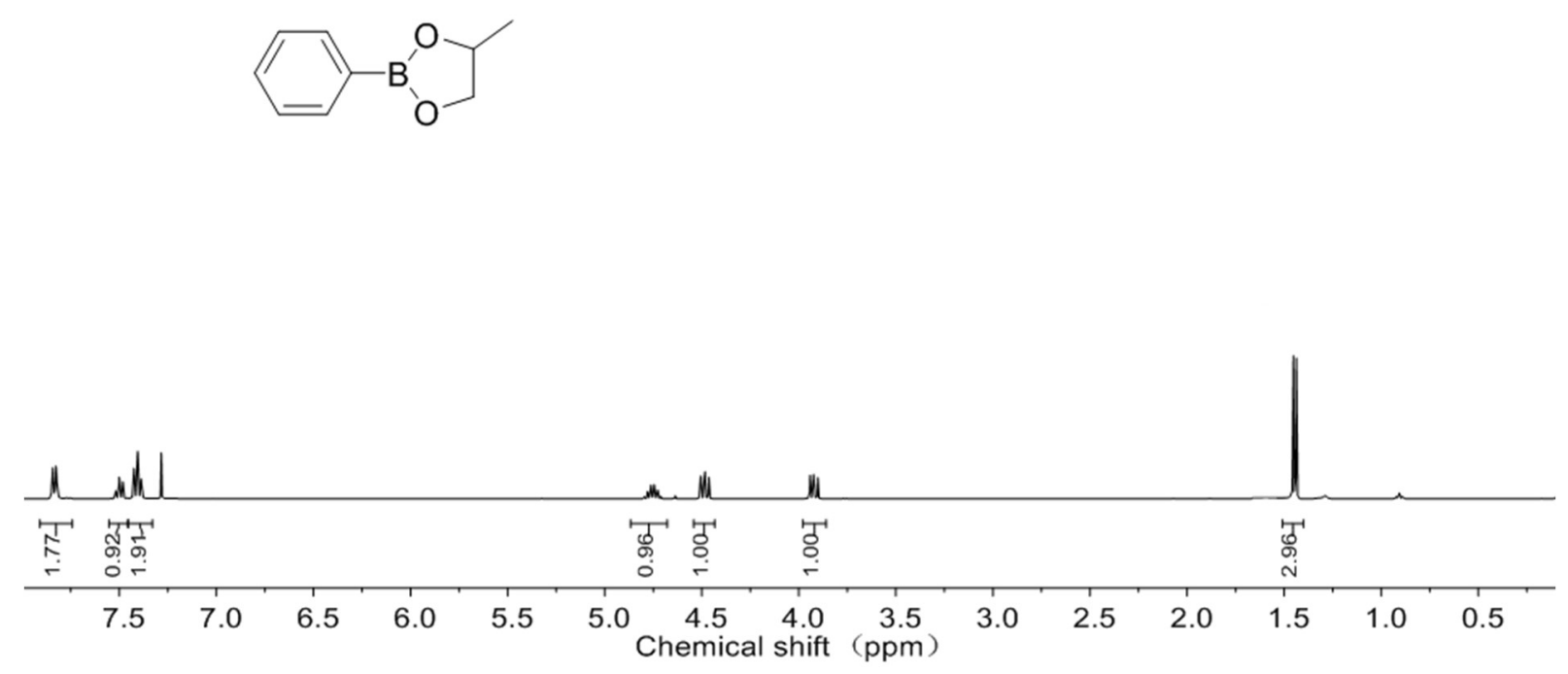

Figure S9. ${ }^{1} \mathrm{H}$ NMR spectrum of $\mathrm{A}_{1}-\mathrm{C}_{1}\left(400 \mathrm{MHz}, \mathrm{CDCl}_{3}\right)$.

\subsection{Preparation of cyclooctadiene dioxaborolane (8)}

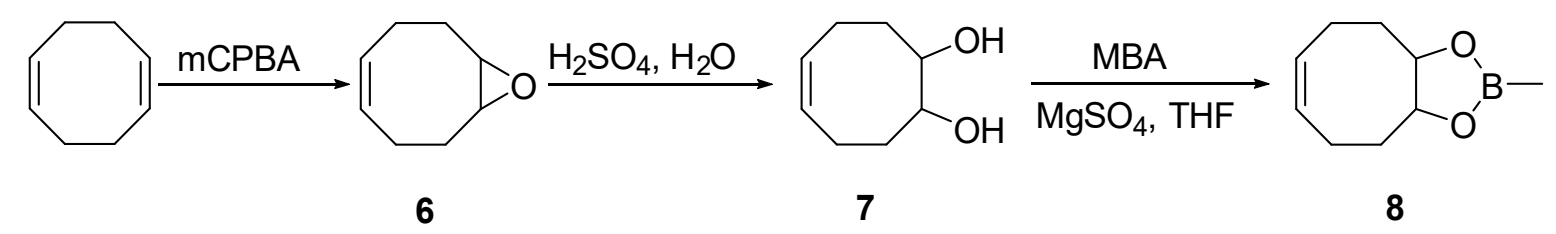

Scheme S2. Synthetic route to cyclooctadiene dioxaborolane (8).

1,2-Diol cyclooctene (7). This compound was prepared from cyclooctadiene according to literature. ${ }^{3}$

Cyclooctene dioxaborolane (8). An oven-dried flask equipped with a stir bar was charged with compound 7 (0.21 g, $1.5 \mathrm{mmol})$, methylboronic acid (89.8 mg, $1.5 \mathrm{mmol}), \mathrm{MgSO}_{4}(0.54$ g, $4.5 \mathrm{mmol}$ ) and $50 \mathrm{~mL}$ THF. After stirring at room temperature for $24 \mathrm{~h}$, the mixture was filtered. Obtained solution was concentrated under reduced pressure to give a crude product. Then, the product was treated with anhydrous hexane, filtered and concentrated under reduced pressure to give the target compound 8 as a colorless oil $(0.22 \mathrm{~g}, 88 \%) .{ }^{1} \mathrm{H} \mathrm{NMR}\left(\mathrm{CDCl}_{3}, 400\right.$

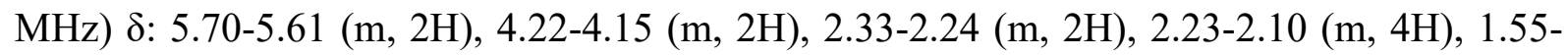
$1.46(\mathrm{~m}, 2 \mathrm{H}), 0.28$ (s, 3H) ppm. ${ }^{13} \mathrm{C} \mathrm{NMR}\left(100 \mathrm{MHz}, \mathrm{CDCl}_{3}\right): \delta$ 129.4, 82.6, 32.0, 21.6 ppm. 
HRMS (ESI-TOF): $m / z$ calculated for $\mathrm{C}_{9} \mathrm{H}_{15} \mathrm{BO}_{2}[\mathrm{M}]^{+}: 165.1196$, found: 165.1194.
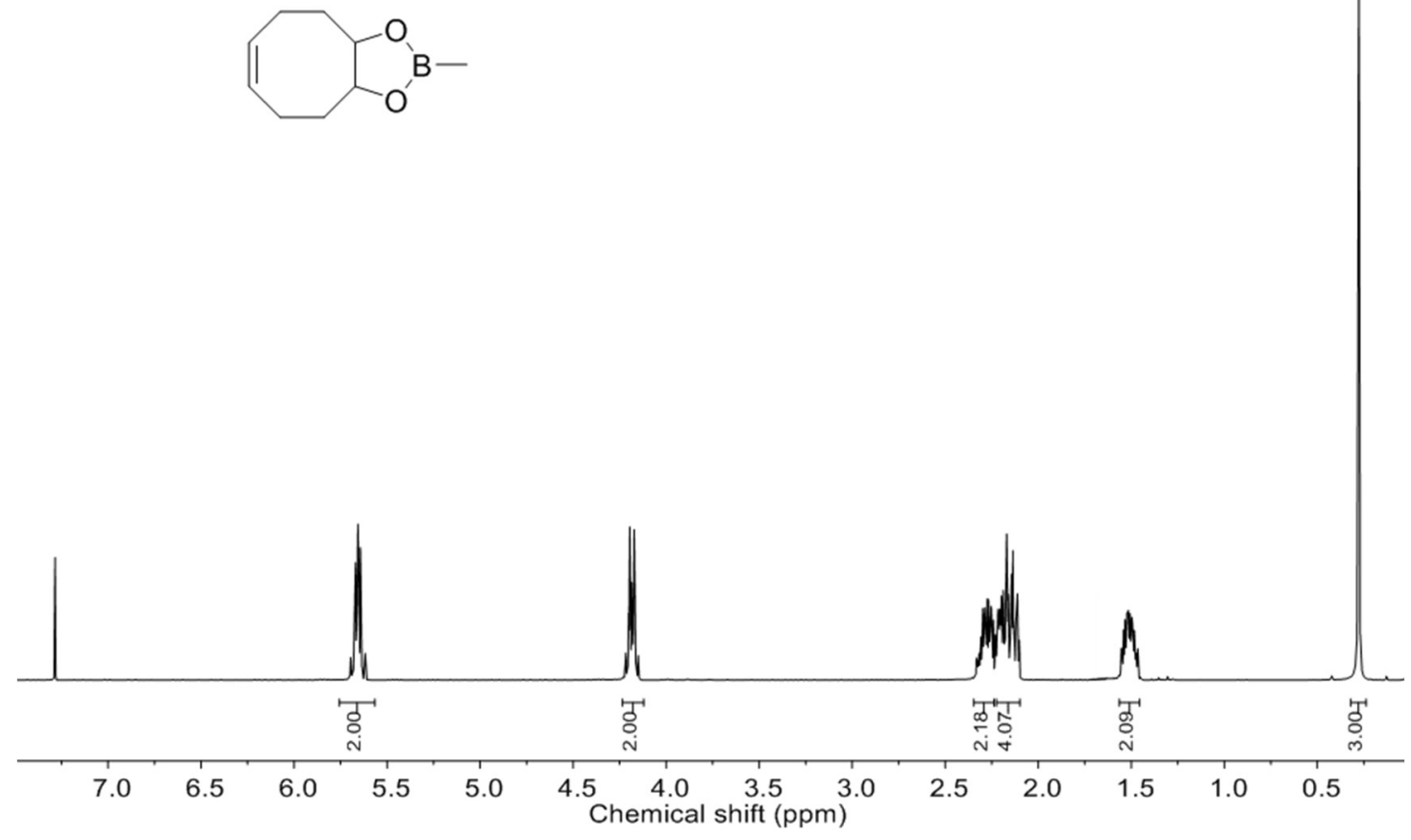

Figure S10. ${ }^{1} \mathrm{H}$ NMR spectrum of compound $8\left(400 \mathrm{MHz}, \mathrm{CDCl}_{3}\right)$.
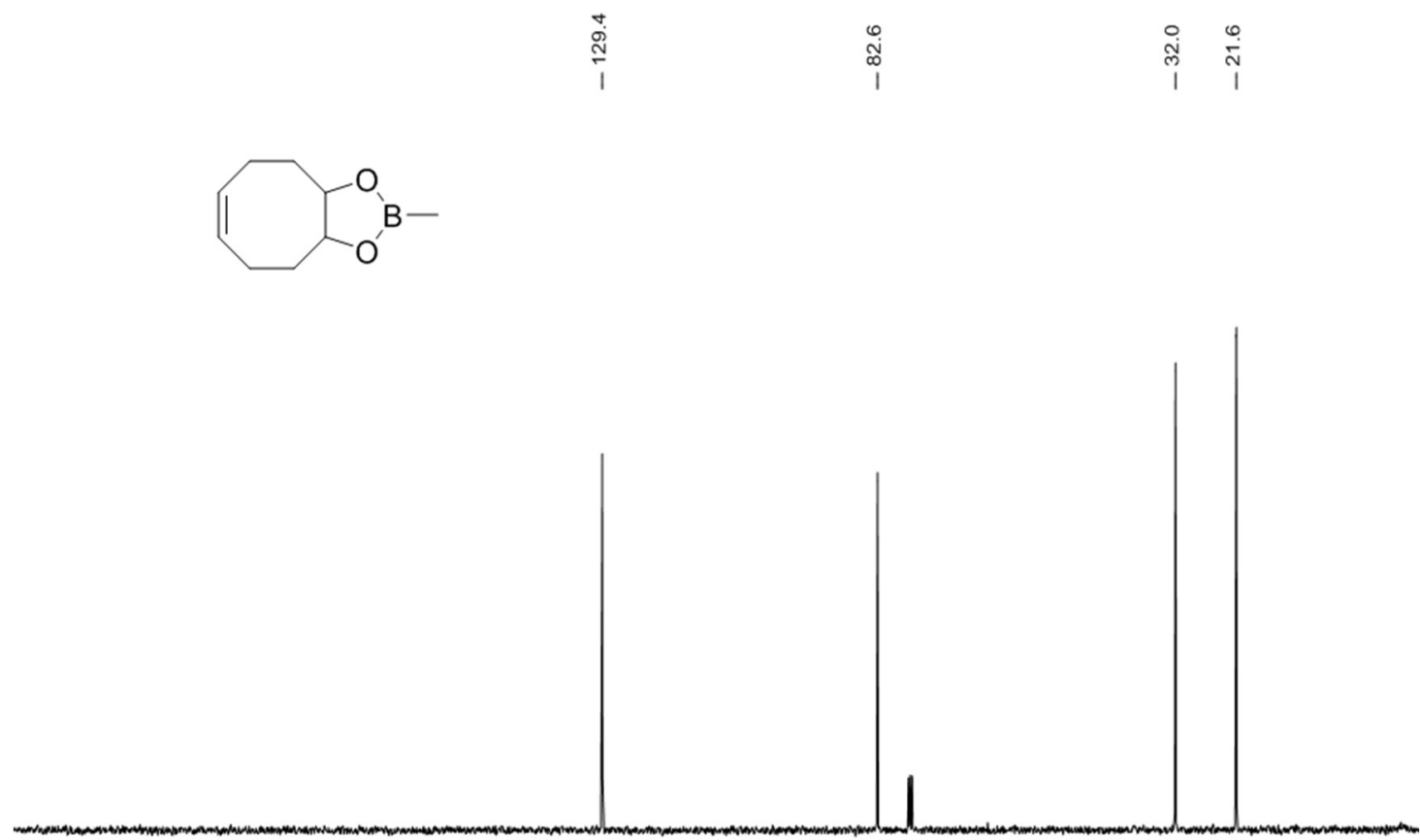

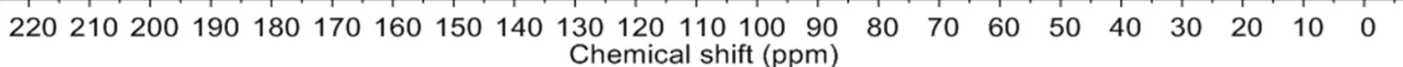

Figure S11. ${ }^{13} \mathrm{C}$ NMR spectrum of compound $8\left(100 \mathrm{MHz}, \mathrm{CDCl}_{3}\right)$. 


\section{Preparation and characterization of polymer networks}

\subsection{Synthesis and characterization of PCOE and PCOE-B}<smiles>CB1OC2CCC=CCCC2O1</smiles>

8

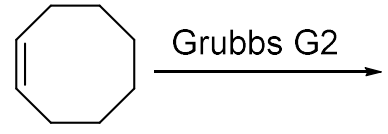

Scheme S3. Synthetic route to PCOE-B.

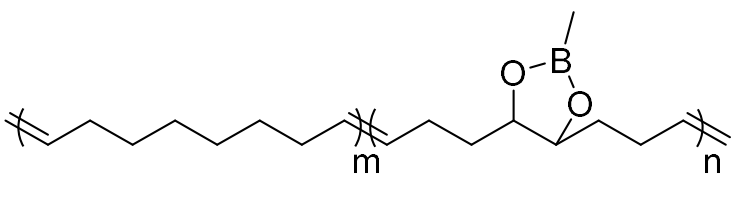

PCOE-B

PCOE-B. A round-bottom flask equipped with a stir bar was charged with cyclooctene (15.93 g, $144.5 \mathrm{mmol})$, monomer 8 (6.00 g, $36.1 \mathrm{mmol})$ and $400 \mathrm{~mL}$ anhydrous DCM. The second generation of Grubbs' catalyst $(30.9 \mathrm{mg}, 0.036 \mathrm{mmol})$ was dissolved in $10 \mathrm{~mL}$ anhydrous DCM and then quickly added into the monomer solution. The reaction mixture was stirred at room temperature for $6 \mathrm{~h}$. After quenching with $10 \mu \mathrm{L} n$-butyl vinyl ether, the polymer was precipitated from methanol to afford desired product as a white solid $(20.92 \mathrm{~g}, 95 \%) \cdot M_{\mathrm{n}}=$ $1.55 \times 10^{5} \mathrm{~g} / \mathrm{mol}, \emptyset=1.89$.<smiles>C=CCCCCCCCCCCC1OB(C)OC1CCC=C</smiles>

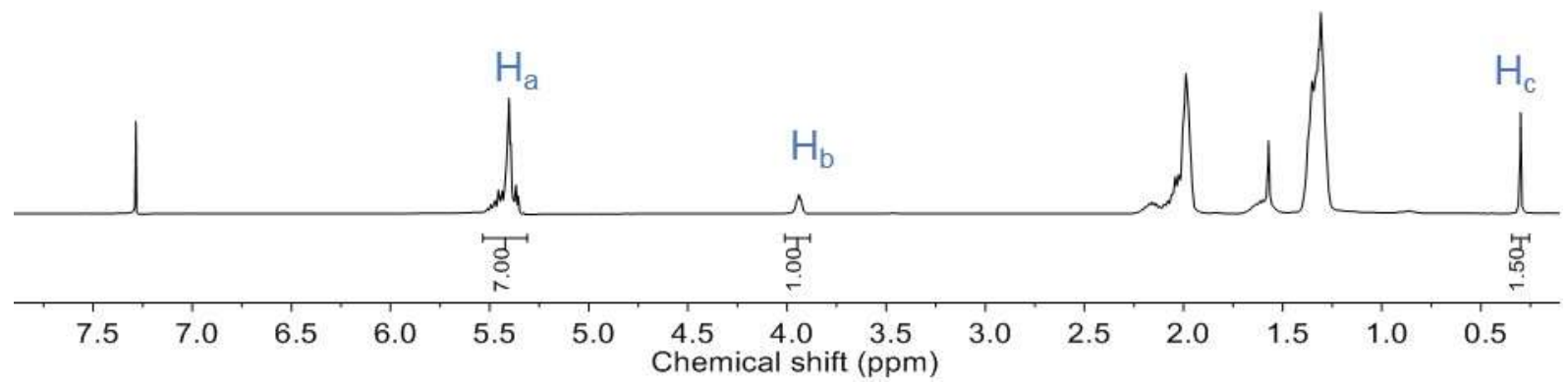

Figure S12. ${ }^{1} \mathrm{H}$ NMR spectrum of PCOE-B $\left(400 \mathrm{MHz}, \mathrm{CDCl}_{3}\right)$. The molar ratio of $\mathrm{m}: \mathrm{n}=\left(\mathrm{H}_{\mathrm{a}}-\right.$ $\left.\mathrm{H}_{\mathrm{b}}\right): \mathrm{H}_{\mathrm{b}}=6: 1$. The discrepancy between feed ratio and incorporation ratio was attributed to the different consumption rates of the two monomers. 


\subsection{Synthesis and characterization of PE-B and PE-B'}

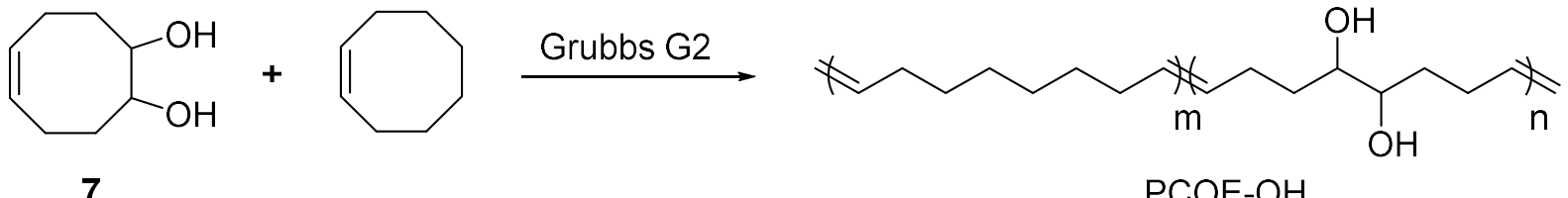

Scheme S4. Synthetic route to PCOE-OH.

PCOE-OH. A round-bottom flask equipped with a stir bar was charged with cyclooctene (4.40 g, $40 \mathrm{mmol})$, monomer $7(1.42 \mathrm{~g}, 10 \mathrm{mmol})$ and $120 \mathrm{~mL}$ anhydrous DCM. The second generation of Grubbs' catalyst $(8.5 \mathrm{mg}, 0.01 \mathrm{mmol})$ was dissolved in $5 \mathrm{~mL}$ anhydrous DCM and then quickly added into the monomer solution. The reaction mixture was stirred at room temperature for $6 \mathrm{~h}$. After quenching with $10 \mu \mathrm{L} n$-butyl vinyl ether, the polymer was precipitated from methanol to afford desired product as white solid $(5.41 \mathrm{~g}, 93 \%) . M_{\mathrm{n}}=1.46 \times$ $10^{5} \mathrm{~g} / \mathrm{mol}, \emptyset=1.83$.
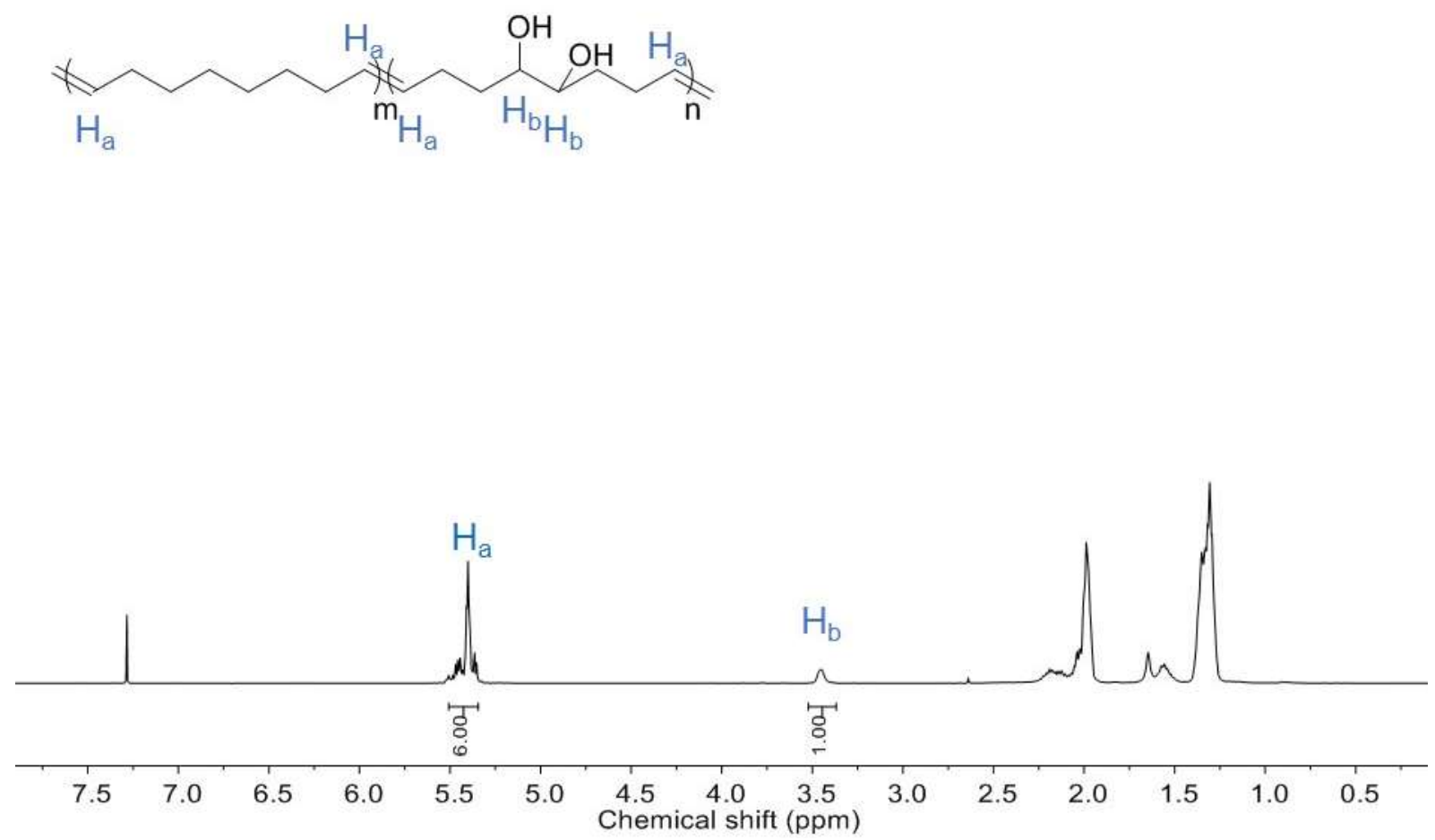

Figure S13. ${ }^{1} \mathrm{H}$ NMR spectrum of PCOE-OH. The molar ratio of $m: n=\left(\mathrm{H}_{\mathrm{a}}-\mathrm{H}_{\mathrm{b}}\right): \mathrm{H}_{\mathrm{b}}=5: 1$. The discrepancy between feed ratio and incorporation ratio was attributed to the different consumption rates of the two monomers. 

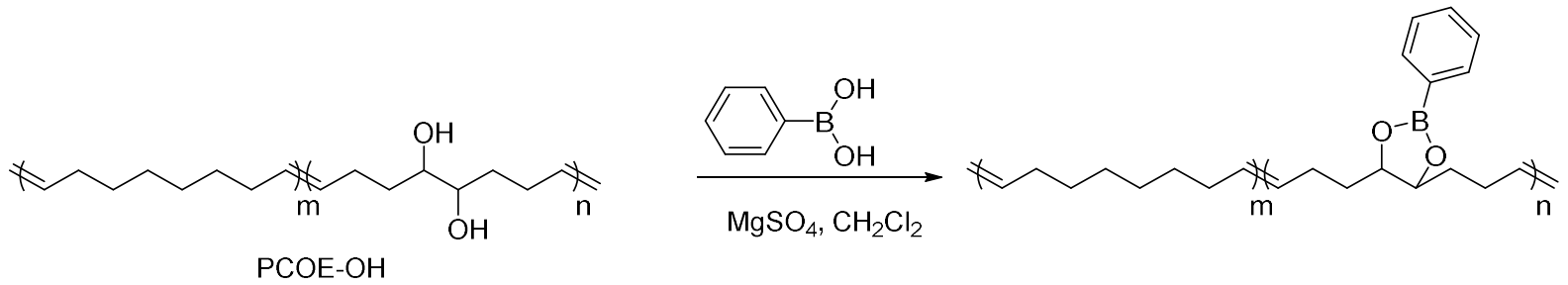

Scheme S5. Synthetic route to PCOE-B'.

PCOE-B'. PCOE-OH (2.00 g) and excessive phenylboronic acid (0.26 g, $2.1 \mathrm{mmol})$ was dissolved into $20 \mathrm{~mL} \mathrm{CH}_{2} \mathrm{Cl}_{2}$ and stirred at room temperature for $2 \mathrm{~h}$. After reaction, $\mathrm{MgSO}_{4}$ (7.20 g, $60 \mathrm{mmol})$ was added and stirred for further $6 \mathrm{~h}$. The solution was filtered and precipitated in anhydrous methanol to obtain the target polymer $(2.18 \mathrm{~g}, 97 \%) \cdot M_{\mathrm{n}}=1.63 \times 10^{5}$ $\mathrm{g} / \mathrm{mol}, Ð=1.86$
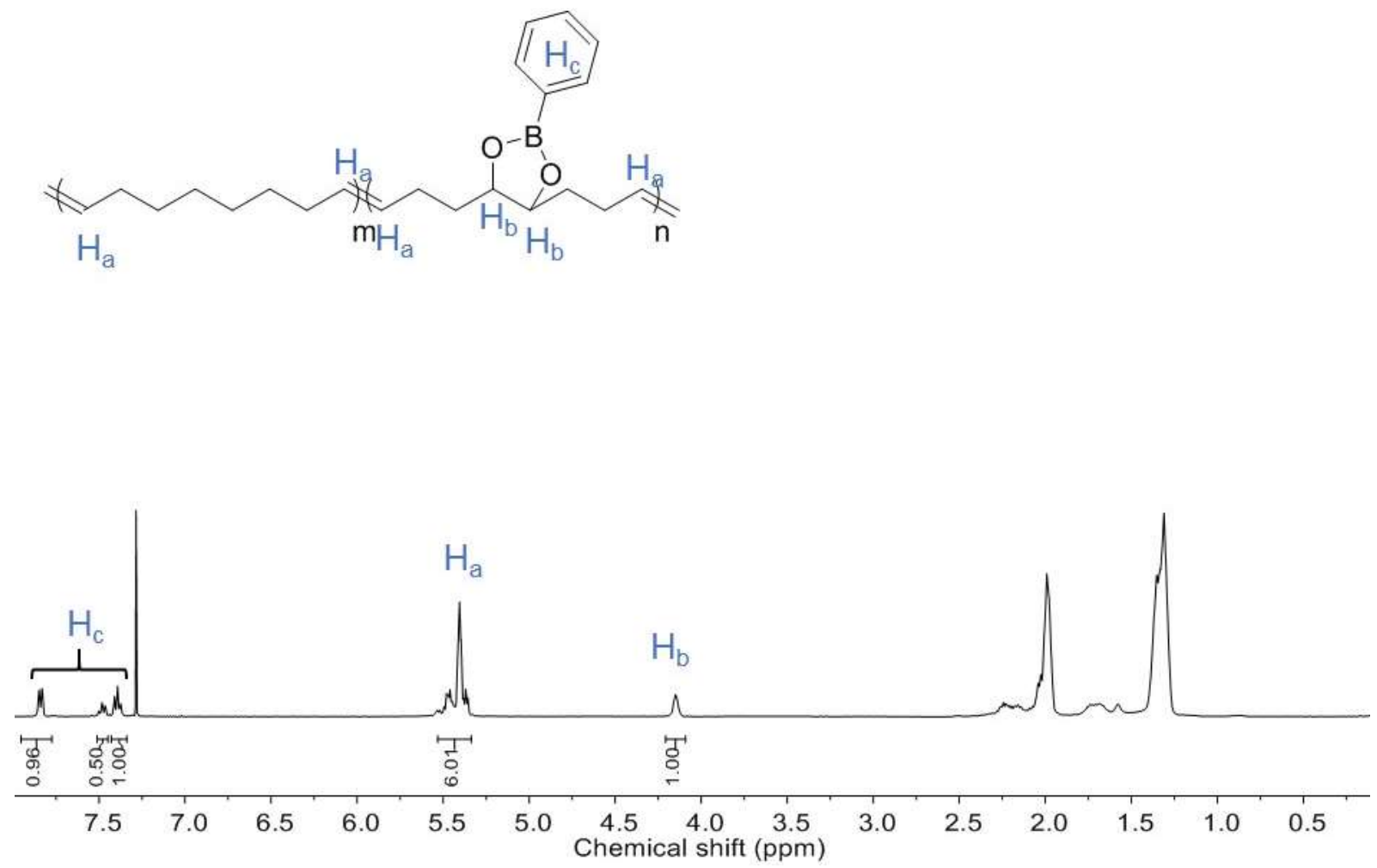

Figure S14. ${ }^{1} \mathrm{H}$ NMR spectrum of PCOE-B'.

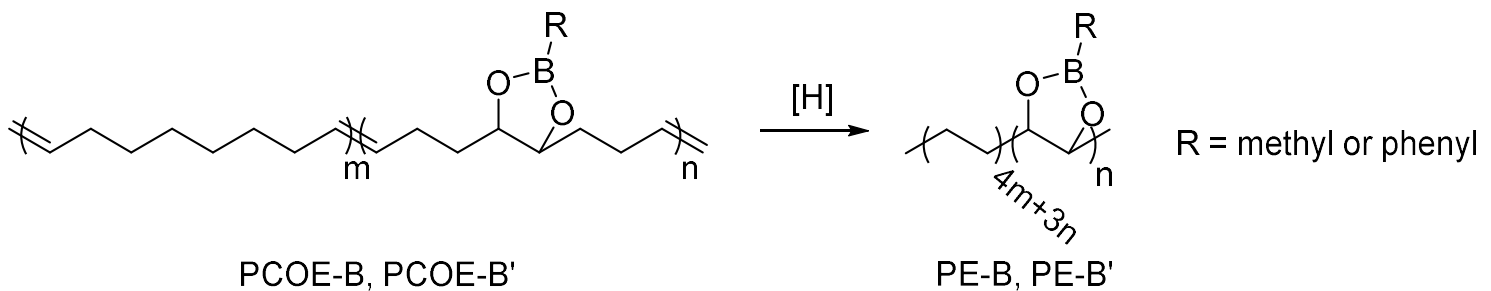

Scheme S6. Hydrogenation of PCOE-B and PCOE-B'. 
PE-B: To a $150 \mathrm{~mL}$ pressure flask, PCOE-B (0.50 g), 4-methylbenzenesulfonhydrazide (4.66 g, $25 \mathrm{mmol}), 2,6$-di-tert-butylphenol (44.0 mg, $0.2 \mathrm{mmol})$, triethylamine $(2.53 \mathrm{~g}, 25$ mmol) were added and mixed with $50 \mathrm{~mL} o$-xylene. The mixture was heated at $120{ }^{\circ} \mathrm{C}$ for $6 \mathrm{~h}$ and then poured into anhydrous methanol to precipitate the hydrogenated polymer. The polymer was filtered and dried under reduced pressure to obtain a white solid $(0.47 \mathrm{~g}, 95 \%)$.

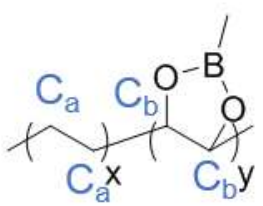

$\begin{array}{llllllllllllllllllll}190 & 180 & 170 & 160 & 150 & 140 & 130 & 120 & \begin{array}{l}110 \\ \text { Chemical shift (ppm) }\end{array}\end{array}$

Figure S15. Solid-state CP/MAS ${ }^{13} \mathrm{C}$ NMR spectrum of PE-B. There is no signal in the range of 120-130 ppm, indicating the successful hydrogenation of PCOE-B.

PE-B': To a $150 \mathrm{~mL}$ pressure flask, PCOE-B' (0.50 g), 4-methylbenzenesulfonhydrazide (4.66 g, $25 \mathrm{mmol}), 2,6$-di-tert-butylphenol (44.1 mg, $0.2 \mathrm{mmol})$, triethylamine (2.53 g, 25 mmol) were added and mixed with $50 \mathrm{~mL} \mathrm{o-xylene.} \mathrm{The} \mathrm{mixture} \mathrm{was} \mathrm{heated} \mathrm{at} 120{ }^{\circ} \mathrm{C}$ for $6 \mathrm{~h}$ and then poured into anhydrous methanol to give the hydrogenated polymer. The polymer was filtered and dried under reduced pressure to give a white solid $(0.48 \mathrm{~g}, 96 \%)$.

\subsection{Preparation of crosslinkers}

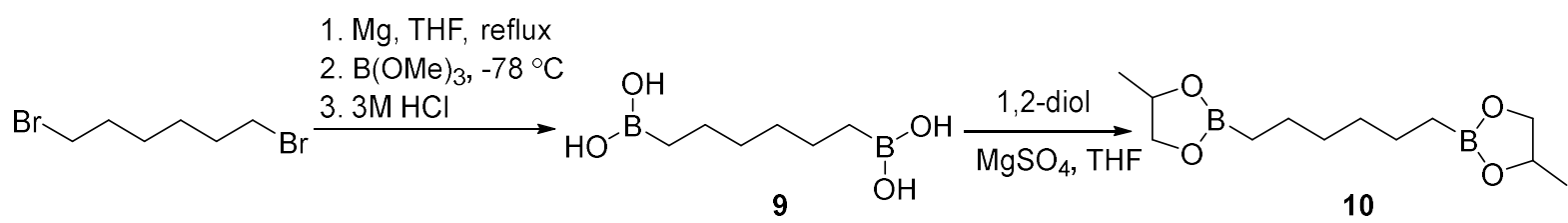

Scheme S7. Synthetic route to alkylboron based crosslinker $\mathbf{1 0 .}$

1,6-(diboronic acid)hexane (9). An oven-dried flask equipped with a stir bar was charged 
with anhydrous THF $(100 \mathrm{~mL})$ and magnesium powder $(3.60 \mathrm{~g}, 150 \mathrm{mmol})$ under $\mathrm{N}_{2}$ atmosphere. 1,6-Dibromohexane $(12.20 \mathrm{~g}, 50 \mathrm{mmol})$ was added into this flask in two portions. The first portion of 1,6-dibromohexane $(1.20 \mathrm{~g})$ was injected and quickly heated the mixture to reflux. The residual 1,6-dibromohexane was added dropwise. The mixture was reacted for additional $2 \mathrm{~h}$. Then, the mixture was cooled to room temperature. The Grignard reagent solution was added dropwise into the pre-cooled solution of trimethylborate $(15.60 \mathrm{~g}, 150 \mathrm{mmol}$, dissolved in $100 \mathrm{~mL}$ anhydrous THF) via a syring at $-78{ }^{\circ} \mathrm{C}$ over $30 \mathrm{~min}$. After addition, the mixture was stirred at $-78{ }^{\circ} \mathrm{C}$ for $1 \mathrm{~h}$. Then, the reaction mixture was slowly warmed to room temperature. $100 \mathrm{~mL} \mathrm{HCl}$ aqueous solution $(3.0 \mathrm{M})$ was slowly added into the flask, and the mixture was stirred overnight at room temperature. After reaction, the mixture was concentrated under vacuum. The precipitated white solid was collected and recrystallized in water, obtained solid was dried under vacuum overnight to afford compound 9 as white solids (0.56 g, 37\%). The product was used directly without further purification and characterization.

1,6-(diboronic ester)hexane (10). An oven-dried flask equipped with a stir bar was charged with compound 9 (1.74 g, $10 \mathrm{mmol})$, 1,2-propanediol (0.80 g, $10.5 \mathrm{mmol}), \mathrm{MgSO}_{4}(7.20 \mathrm{~g}, 60$ $\mathrm{mmol}$ ) and $50 \mathrm{~mL}$ THF. After stirring at room temperature for $6 \mathrm{~h}$, the mixture was filtered. Obtained solution was concentrated under reduced pressure to give crude product. Then, the product was treated with anhydrous hexane, filtered and concentrated under reduced pressure to give the target compound $\mathbf{1 0}$ as a colorless oil $(0.22 \mathrm{~g}, 88 \%) .{ }^{1} \mathrm{H} \mathrm{NMR}\left(\mathrm{CDCl}_{3}, 400 \mathrm{MHz}\right) \delta$ : $4.48-4.56(\mathrm{~m}, 2 \mathrm{H}), 4.26(\mathrm{t}, J=8.0,2 \mathrm{H}), 3.70(\mathrm{dd}, J=8.8 \mathrm{~Hz}, 1.6 \mathrm{~Hz}, 2 \mathrm{H}), 1.44-1.39(\mathrm{~m}, 4 \mathrm{H})$, 1.33-1.29 (m, 10H), $0.83(\mathrm{t}, J=8.0 \mathrm{~Hz}, 4 \mathrm{H}) \mathrm{ppm} .{ }^{13} \mathrm{C} \mathrm{NMR}\left(100 \mathrm{MHz}, \mathrm{CDCl}_{3}\right): \delta 72.9,71.9$, 32.1, 23.9, 21.8 ppm. HRMS (ESI-TOF): $\mathrm{m} / z$ calculated for $\mathrm{C}_{12} \mathrm{H}_{24} \mathrm{~B}_{2} \mathrm{O}_{4}[\mathrm{M}]^{+}: 252.1928$, found: 252.1934 . 

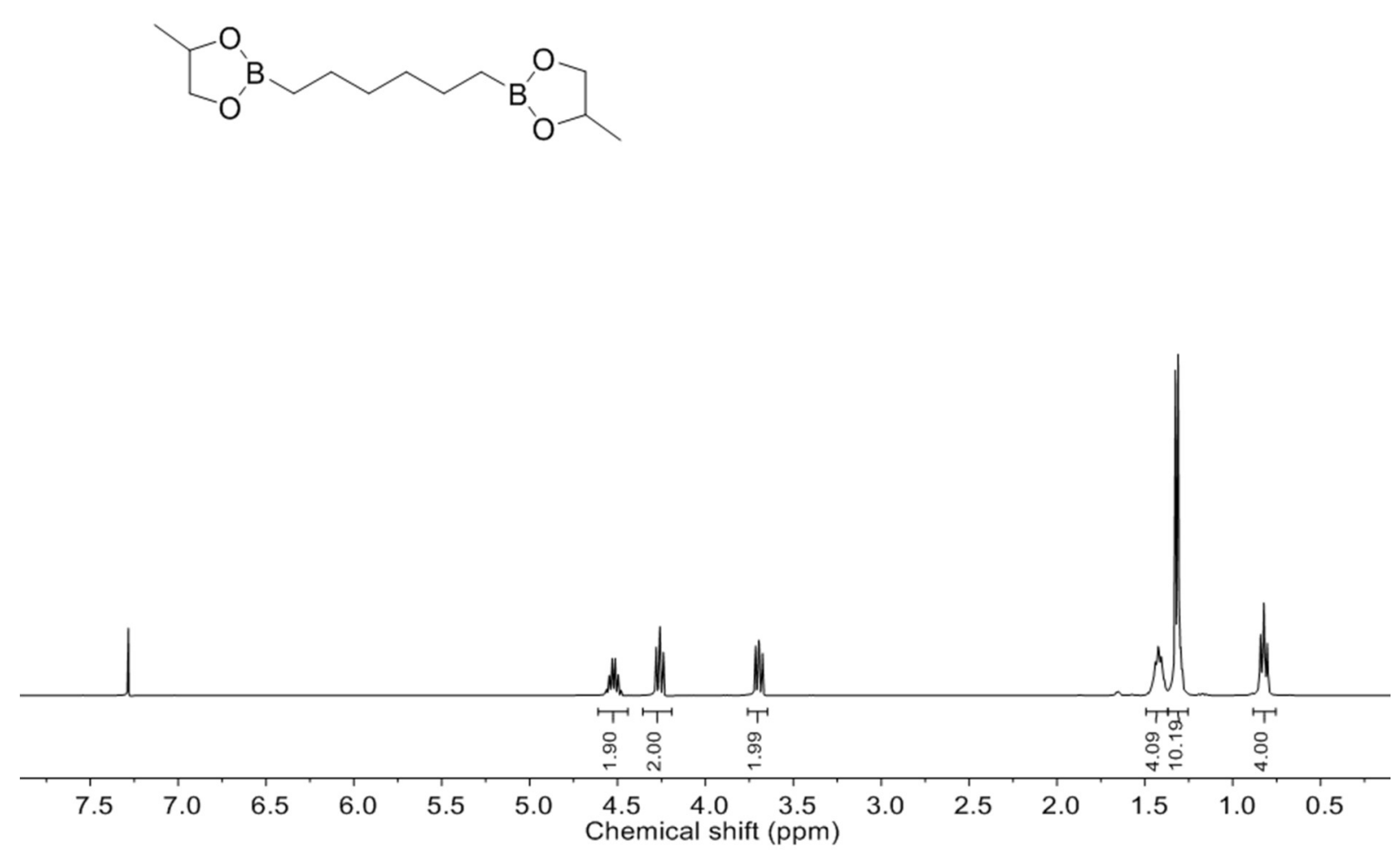

Figure S16. ${ }^{1} \mathrm{H}$ NMR spectrum of Compound $10\left(400 \mathrm{MHz}, \mathrm{CDCl}_{3}\right)$.
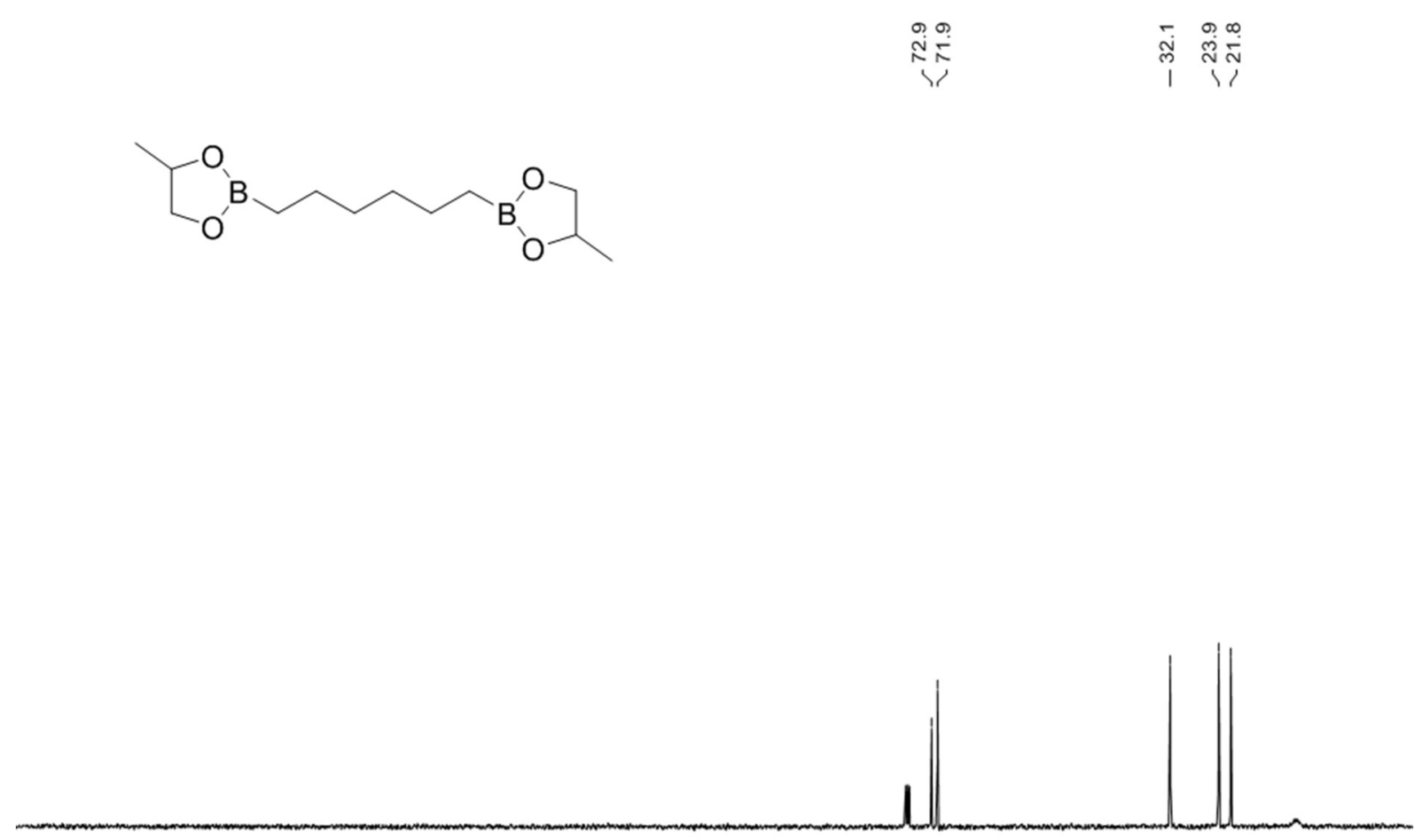

$220210200190180170160150140 \begin{array}{llllllllllllllllll}130 & 120 & 110 & 100 & 90 & 80 & 70 & 60 & 50 & 40 & 30 & 20 & 10 & 0\end{array}$

Figure S17. ${ }^{13} \mathrm{C}$ NMR spectrum of Compound $10\left(100 \mathrm{MHz}, \mathrm{CDCl}_{3}\right)$. 


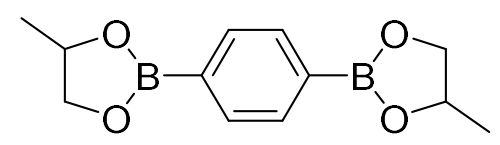

11

Scheme S8. Molecular structure of arylboron based crosslinker.

Arylboronic ester crosslinker compound $\mathbf{1 1}$ was prepared according to the literature. ${ }^{4}$

\subsection{Synthesis of PE-AB and PE-PB}
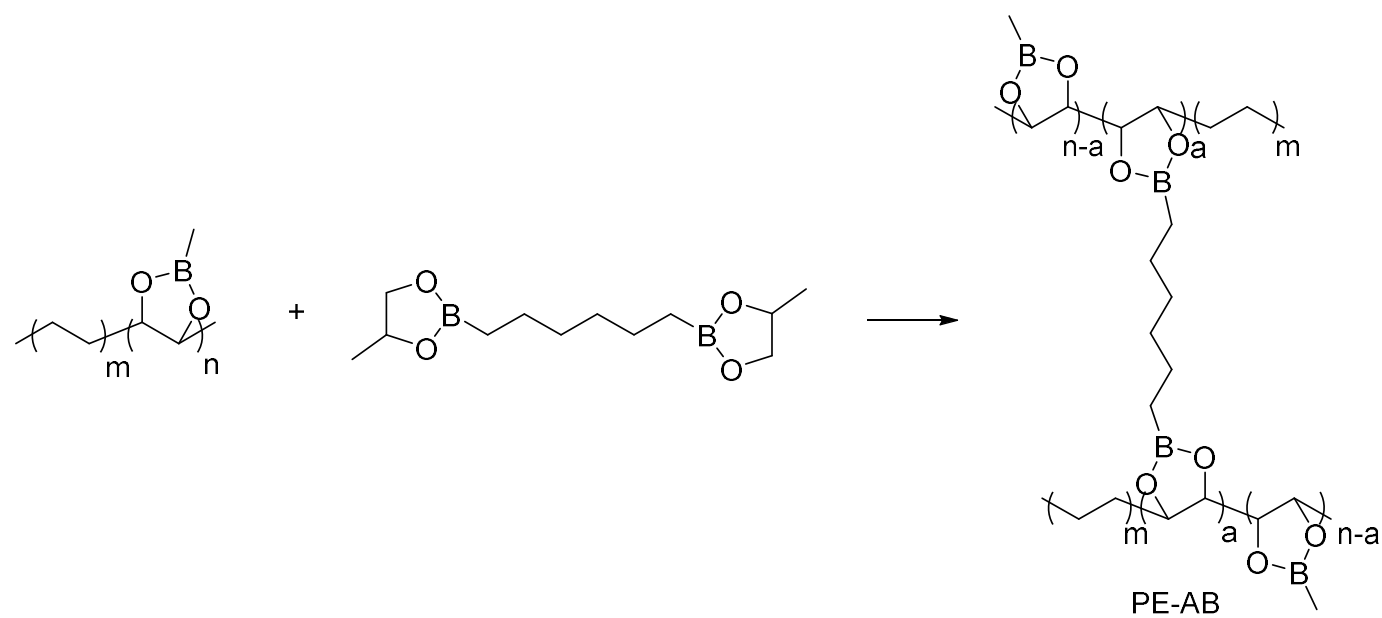

Scheme S9. Preparation of PE-AB.

In a $100 \mathrm{~mL}$ round-bottom flask, $2.00 \mathrm{~g}$ PE-B was dissolved in $50 \mathrm{~mL} o$-xylene at $120{ }^{\circ} \mathrm{C}$. Cross-linker of compound $10(16.9 \mathrm{mg})$ was dissolved in $2 \mathrm{~mL}$ o-xylene and added quickly into the flask with vigorous stirring. Gelation was observed in $10 \mathrm{~s}$. After reaction, solvent and generated side product were removed under vacuum to give cross-linked polymer of PE-AB. $0.1 \mathrm{~mol} \%$ Crosslinker was used with respect to the repeat units of PE-B, giving a crosslinking degree $\left(C_{D}\right)$ of $0.2 \%$.

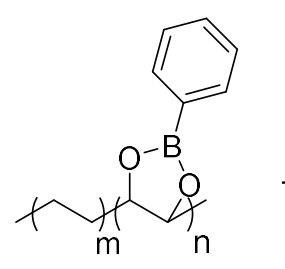

$\left[\begin{array}{l}O \\ 0\end{array}\right.$

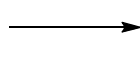

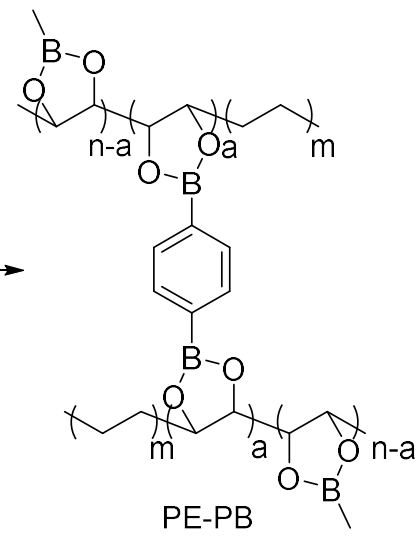

Scheme S10. Preparation of PE-PB. 
In a $100 \mathrm{~mL}$ round-bottom flask, $2.00 \mathrm{~g}$ PE-B' was dissolved in $50 \mathrm{~mL} o$-xylene at $120{ }^{\circ} \mathrm{C}$. Crosslinker of compound 11 (14.9 mg) was dissolved in $2 \mathrm{~mL} o$-xylene and added quickly into this flask with vigorous stirring. Gelation was observed in $10 \mathrm{~s}$. After reaction, solvent and generated byproduct were removed under vacuum to give cross-linked polymer of PE-PB. 0.1 mol\% Crosslinker was used with respect to the repeat units of PE-B, giving a crosslinking degree $\left(\mathrm{C}_{\mathrm{D}}\right)$ of $0.2 \%$.

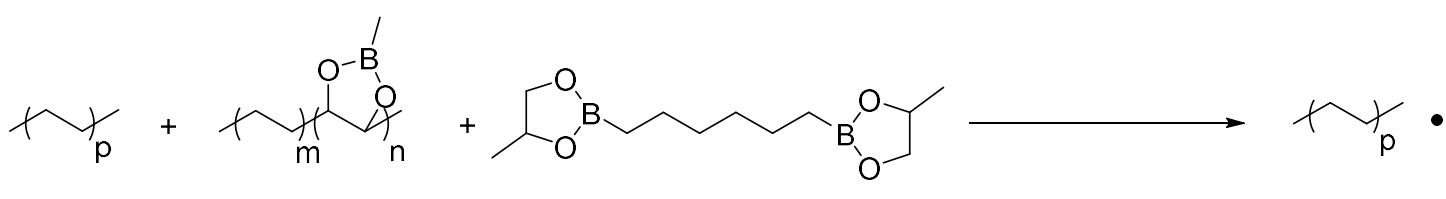

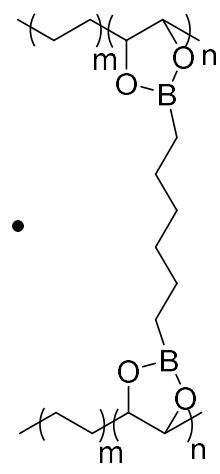

PE/PE-AB

Scheme S11. Synthesis of PE/PE-AB ${ }_{x}$ materials, where $x=$ mass fraction of PE-AB.

General procedure: In a $100 \mathrm{~mL}$ round-bottom flask, PE-B and commercial PE were dissolved in $20 \mathrm{~mL} o$-xylene at $120^{\circ} \mathrm{C}$. Crosslinker of compound $\mathbf{1 0}$ was dissolved in $2 \mathrm{~mL} o$ xylene and added into the flask quickly with vigorous stirring. After reaction, the solvent and small molecules generated during reaction were removed under vacuum to give $\mathrm{PE} / \mathrm{PE}-\mathrm{AB}_{\mathrm{x}}(\mathrm{x}$ $=$ mass fraction of $\mathrm{PE}-\mathrm{AB}$ in $\mathrm{PE} / \mathrm{PE}-\mathrm{AB})$. The feed ration was summarized in Table $\mathrm{S} 1$.

Table S1. Feed ratios of ingredients employed to prepare $\mathrm{PE} / \mathrm{PE}-\mathrm{AB}_{\mathrm{x}}$.

\begin{tabular}{ccccc}
\hline \multirow{2}{*}{ Entry } & Sample & LDPE & PE-B & Crosslinker \\
& & $(\mathrm{g})$ & $(\mathrm{g})$ & $(\mathrm{mg})$ \\
\hline 1 & $\mathrm{PE} /{\mathrm{PE}-\mathrm{AB}_{0.05}}$ & 1.90 & 0.10 & 15.3 \\
\hline 2 & $\mathrm{PE} / \mathrm{PE}-\mathrm{AB}_{0.1}$ & 1.80 & 0.20 & 31.0 \\
\hline 3 & $\mathrm{PE} /{\mathrm{PE}-\mathrm{AB}_{0.2}}$ & 1.60 & 0.40 & 62.0 \\
\hline
\end{tabular}

Mechanical blending. Taking PE/PE-AB 0.05 as an example: PE (38.00 g) and PE-B (2.00 g) was added into a pre-heated $\left(160^{\circ} \mathrm{C}\right)$ chamber with internal mixer where the rollers were rotated 
with a constant speed of $100 \mathrm{rpm}$. After mixing for $5 \mathrm{~min}$, alkyl boronic ester crosslinker (10) $(0.30 \mathrm{~g})$ was added dropwise into the chamber. 5 min later, the material was taken out for further analysis.

\section{Swelling and hydrolysis experiments}

In swelling experiment, PE-AB samples were immersed in organic solvents of DCM, THF, $\mathrm{PhMe}, o$-xylene and DMSO at room temperature. Three days later, volumes of samples were unchanged (Figure S18a). When $o$-xylene was used and heated at $120{ }^{\circ} \mathrm{C}$ for $3 \mathrm{~h}$, a solventswollen gel was obtained (Figure S18b), manifesting the cross-linked nature of PE-AB. When propanediol was added into $\mathrm{PE}-\mathrm{AB}$, the sample gradually and completely dissolved in o-xylene at $120{ }^{\circ} \mathrm{C}$.

(a)
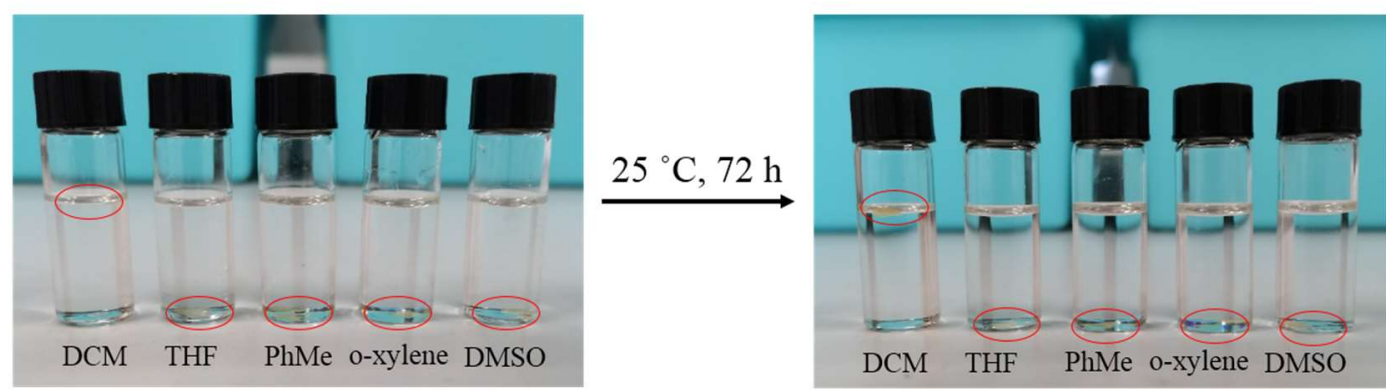

(b)
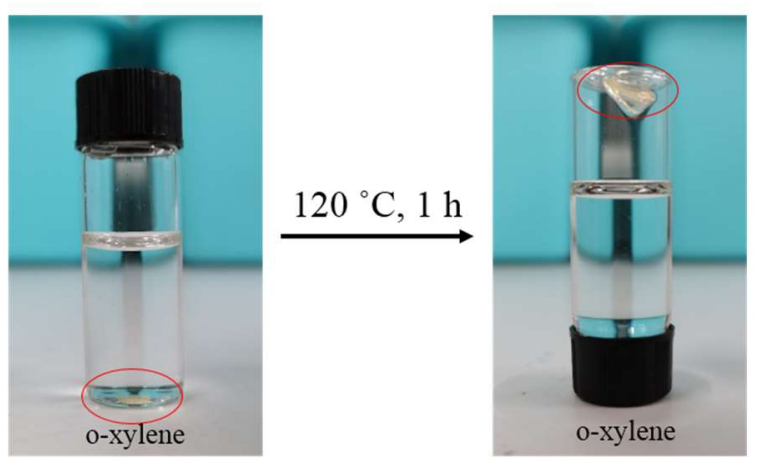

Figure S18. Swelling experiment of PE-AB in different organic solvents.

The swelling ratio and soluble fraction of the thermosets can be calculated using Equations $\mathrm{S} 1$ and $\mathrm{S} 2$, and the results were summarized in Table $\mathrm{S} 2$. In two equations, $\mathrm{m}_{\text {swollen }}$ and $\mathrm{m}_{\text {dried }}$ represent the weight of the swollen and dried materials, respectively.

$$
\begin{array}{cc}
\text { Swelling ratio }=\frac{m_{\text {swollen }}-m_{\text {dried }}}{m_{\text {dried }}} & \text { Equation S1 } \\
\text { Soluble fraction }=\left(1-\frac{m_{\text {dried }}}{m_{\text {dry }}}\right) \times 100 \% & \text { Equation S2 }
\end{array}
$$


Table S2. Swelling experiments of PE-AB samples in common organic solvents.

\begin{tabular}{|c|c|c|}
\hline Solvent & Swelling ratio & Soluble fraction $(\%)$ \\
\hline $\mathrm{DCM}^{\mathrm{a}}$ & 1.1 & $<0.1$ \\
\hline $\mathrm{THF}^{\mathrm{a}}$ & 0.4 & $<0.1$ \\
\hline $\mathrm{PhMe}^{\mathrm{a}}$ & 1.4 & $<0.1$ \\
\hline$o$-xylene ${ }^{\mathrm{a}}$ & 1.7 & $<0.1$ \\
\hline $\mathrm{DMSO}^{\mathrm{a}}$ & $<0.1$ & $<0.1$ \\
\hline$o$-xylene ${ }^{\mathrm{b}}$ & 10.2 & 3.6 \\
\hline$o$-xylene + propanediol $^{\mathrm{b}}$ & dissolved & 100 \\
\hline
\end{tabular}

a Tested at room temperature for $72 \mathrm{~h} .{ }^{\mathrm{b}}$ Tested at $120{ }^{\circ} \mathrm{C}$ for $3 \mathrm{~h}$.

In hydrolysis experiments, to investigate the chemical stability of $\mathrm{C}-\mathrm{B}$ bonds substituted by alkyl and aryl groups, PCOE-B and PCOE-B' were used. Taking PCOE-B as an example.

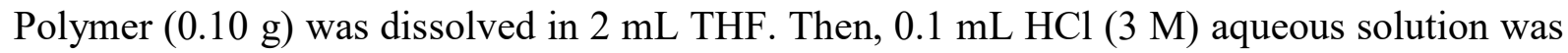
added into the mixture. After stirring at room temperature for $6 \mathrm{~h}$, the mixture was added into methanol to give polymer solids. The obtained solids were analyzed by ${ }^{1} \mathrm{H}$ NMR as shown in Figure S19. The characterization results indicate that the alkyl and aryl boronic esters decomposed for about $10 \%$ and $19 \%$, respectively, indicating that alkyl boronic ester is much more stable than the aryl counterpart, and consistent with the observed dynamic exchanging results in Figure 2 of the manuscript. 

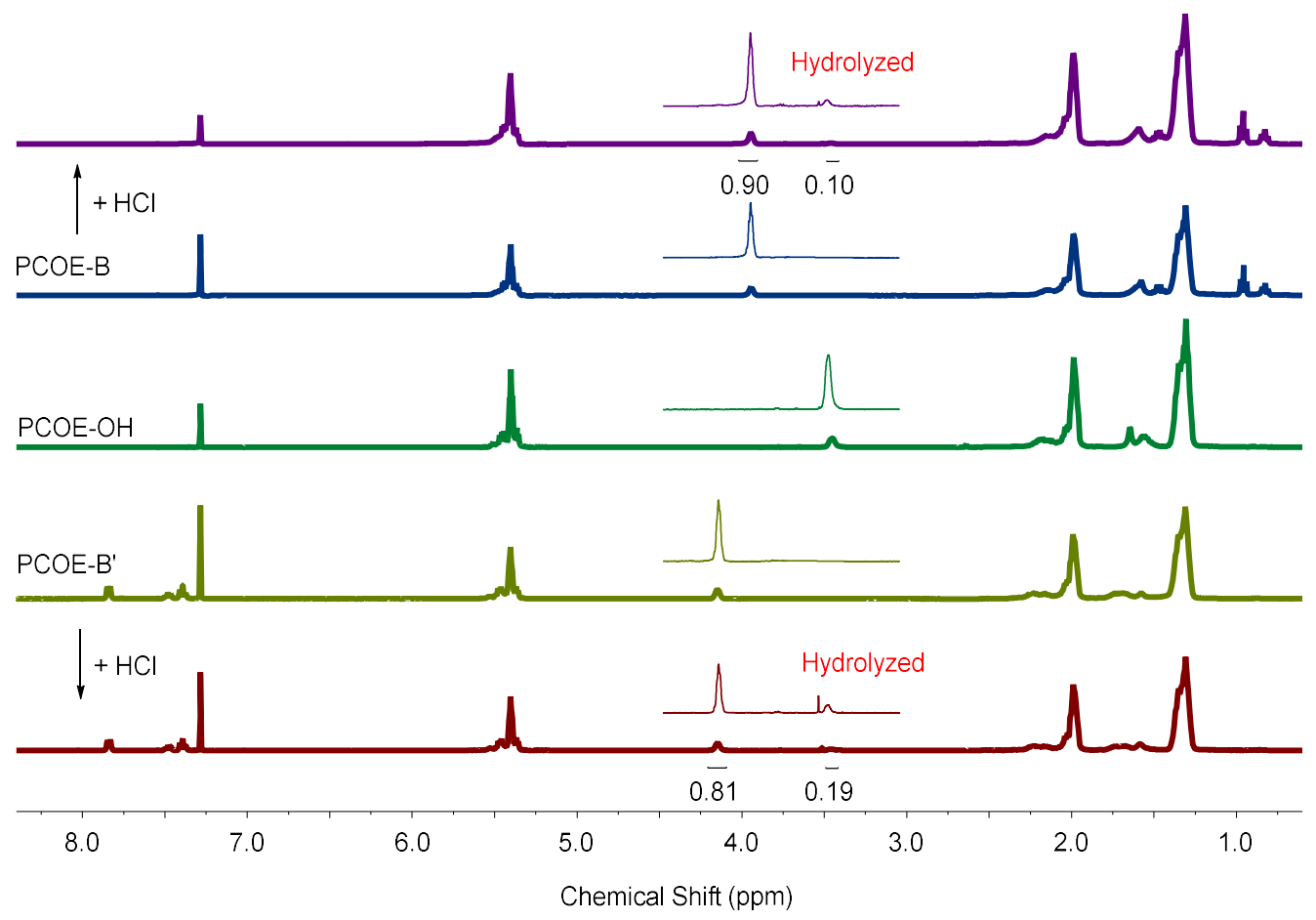

Figure S19. ${ }^{1} \mathrm{H}$ NMR analysis for the hydrolysis of PCOE-B and PCOE-B'.

\section{Characterizations of PE materials}

(a)

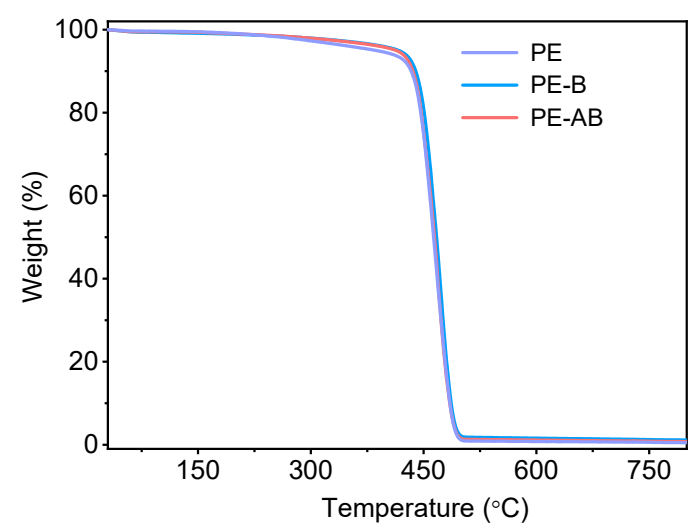

(b)

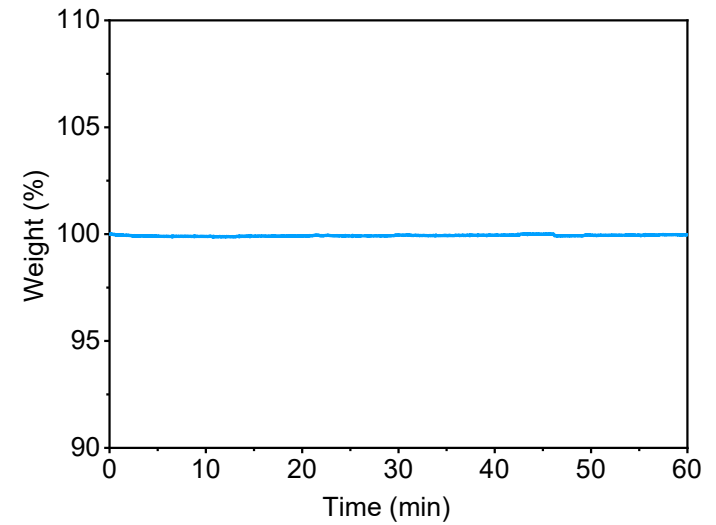

Figure S20. Thermogravimetric analysis of PE, PE-B and PE-AB under nitrogen atmosphere (a), and under air atmosphere at $160{ }^{\circ} \mathrm{C}$ for 1 hour. 
(a)

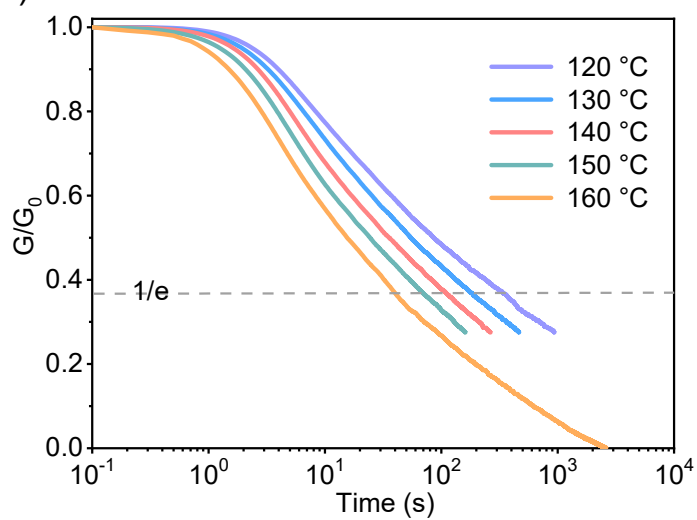

(b)

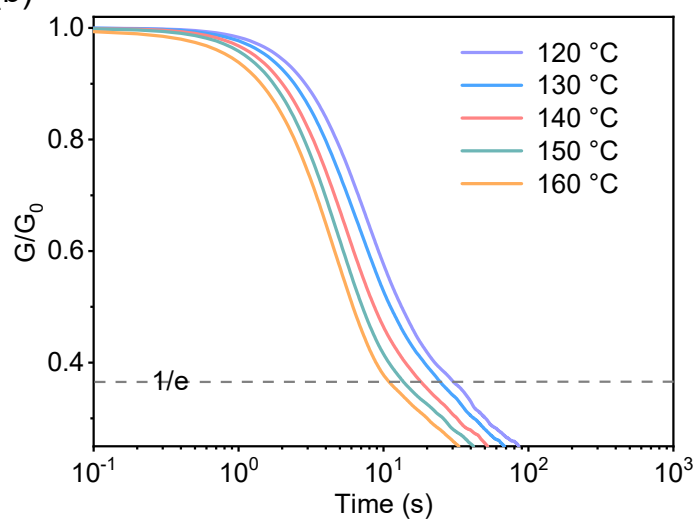

Figure S21. Stress relaxation curves of PE-AB (a) and PE-PB (b).

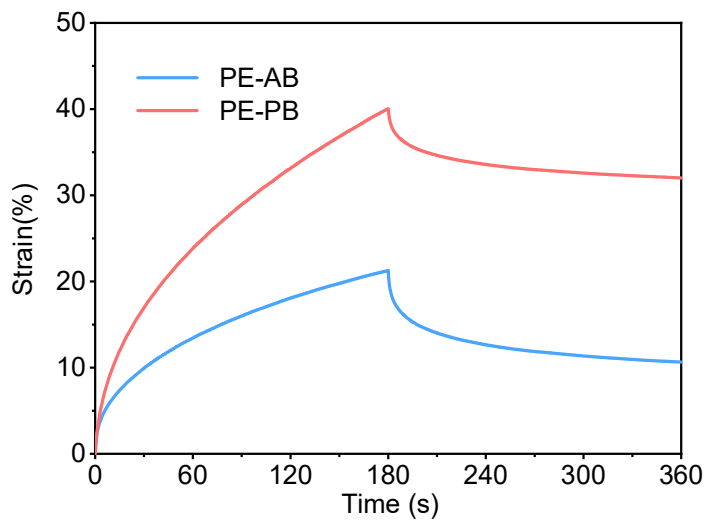

Figure S22. Creep-recovery experiments of PE-AB and PE-PB at $160{ }^{\circ} \mathrm{C}$ with a stress of $10^{4}$ $\mathrm{Pa}$.

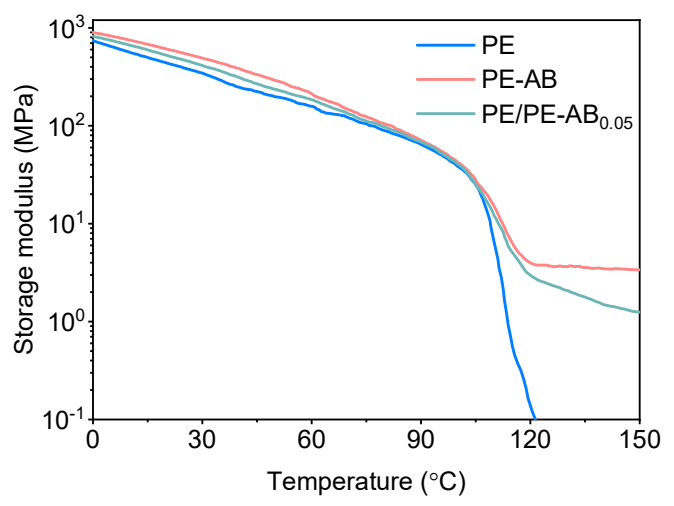

Figure S23. Dynamic mechanical analysis of PE-AB, PE/PE-AB 0.05 and PE. 

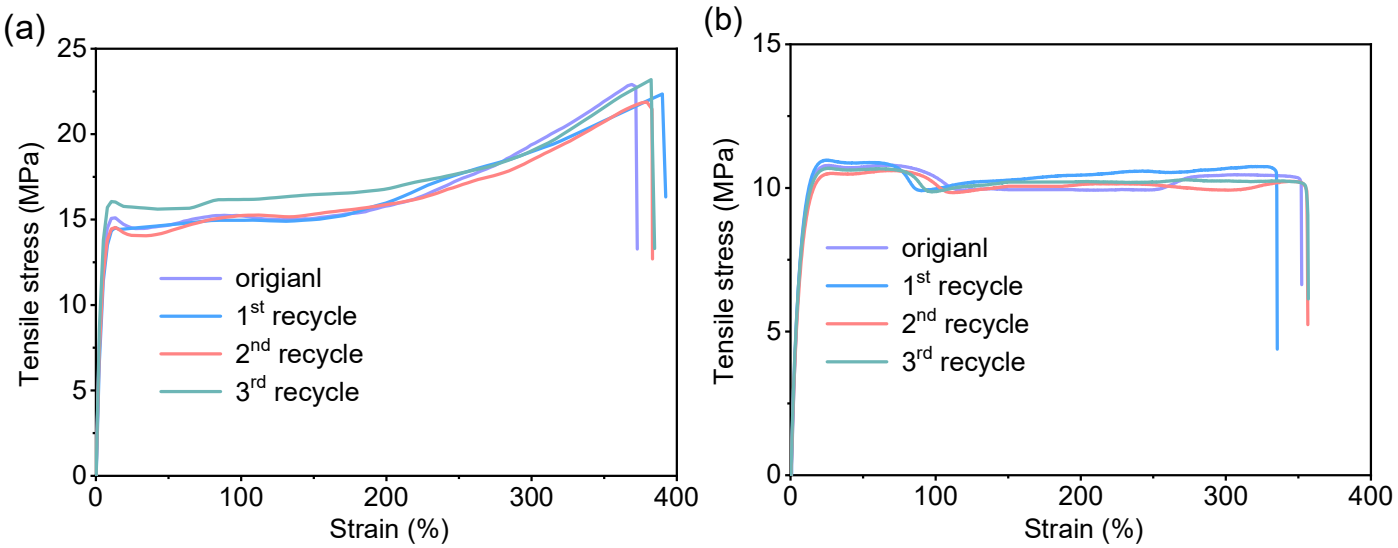

Figure S24. Stress-strain curves of original and re-processed PE materials tested at room temperature. (a) PE-AB; (b) PE/PE-AB ${ }_{0.05}$. The mechanical properties are summarized in Table S2.

Table S2. Mechanical properties of original and reprocessed PE-based materials.

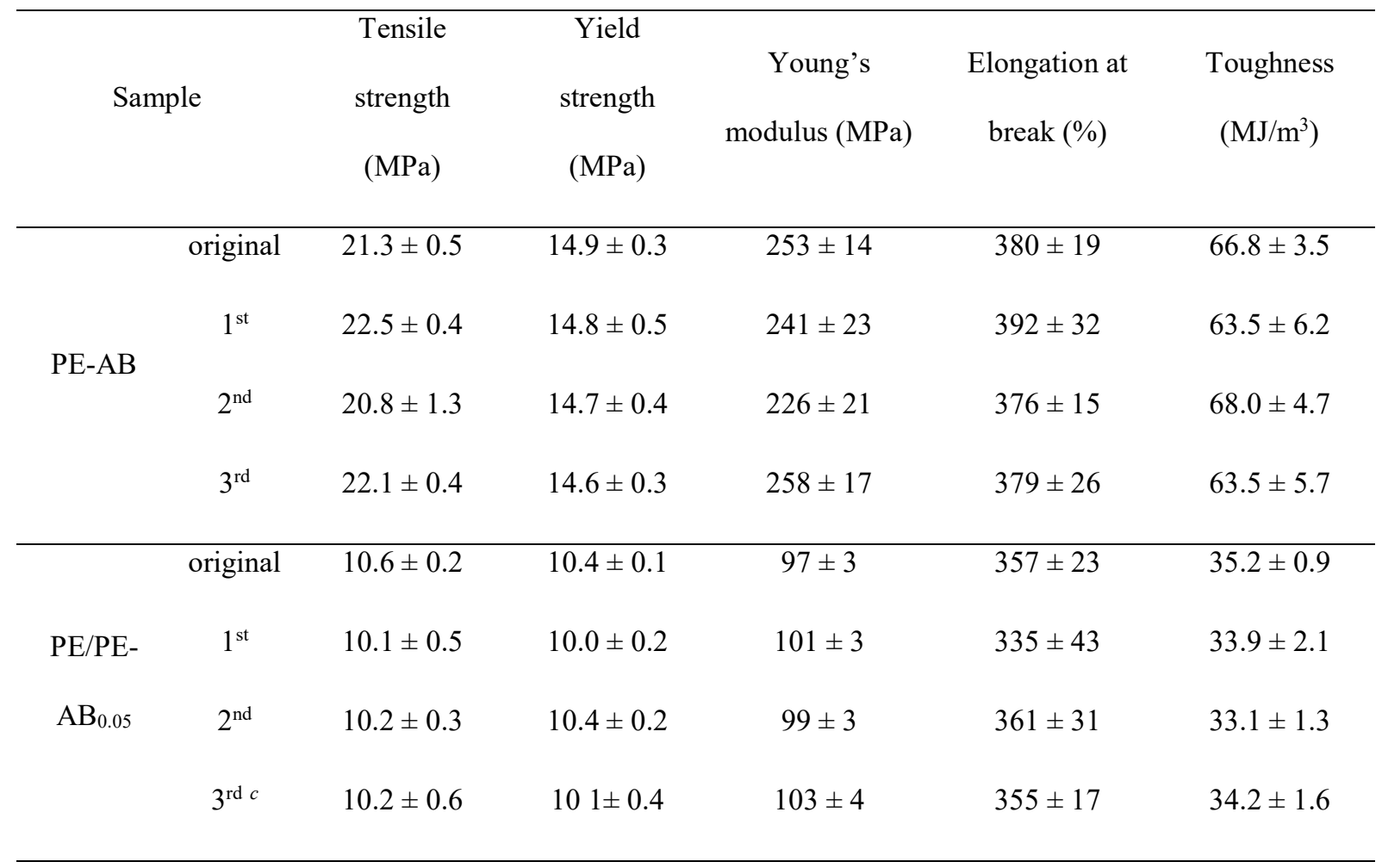


(a)

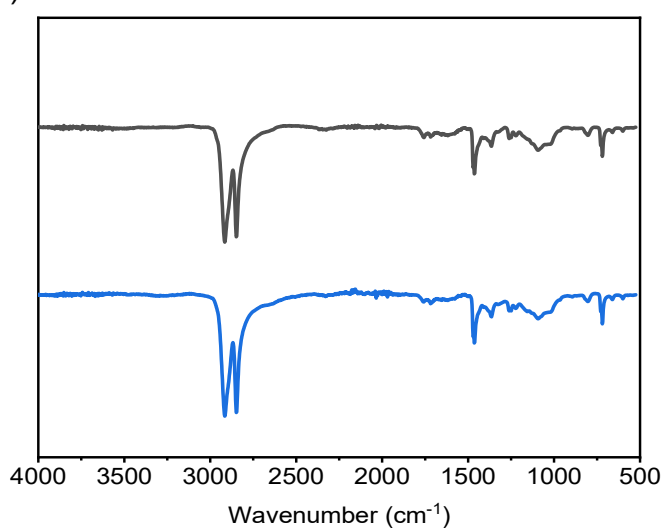

(b)

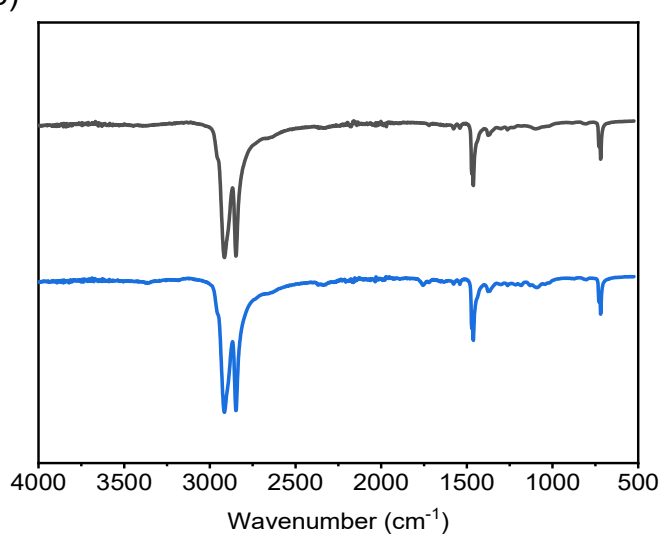

Figure S25. ATR-IR spectra of original and reprocessed PE-based materials. (a) Original (black) and reprocessed samples (blue, reprocessed for three times) of PE-AB; (b) Original (black) and reprocessed samples (blue, reprocessed for three times) of $\mathrm{PE} / \mathrm{PE}-\mathrm{AB}_{0.05}$.

\section{REFERENCE}

(1) Röttger, M.; Domenech, T.; van der Weegen, R.; Breuillac, A.; Nicolä̈, R.; Leibler, L. Highperformance Vitrimers From Commodity Thermoplastics Through Dioxaborolane Metathesis. Science 2017, 356, 62-65.

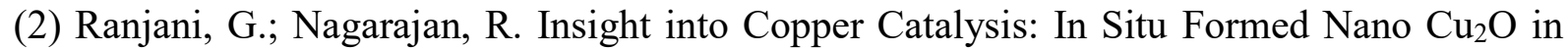
Suzuki-Miyaura Cross-Coupling of Aryl/Indolyl Boronates. Org. Lett. 2017, 19, 3974-3977.

(3) Cromwell, O. R.; Chung, J.; Guan, Z. Malleable and Self-Healing Covalent Polymer Networks through Tunable Dynamic Boronic Ester Bonds. J. Am. Chem. Soc. 2015, 137, 64926495.

(4) Wang, Z.; Gu, Y.; Ma, M.; Chen, M. Strong, Reconfigurable, and Recyclable Thermosets Cross-Linked by Polymer-Polymer Dynamic Interaction Based on Commodity Thermoplastics. Macromolecules 2020, 53, 956-964. 